\title{
Nuclear Technology Research and Development (NTRD) Technical Monthly June FY18
}

\author{
Various
}

August 2018

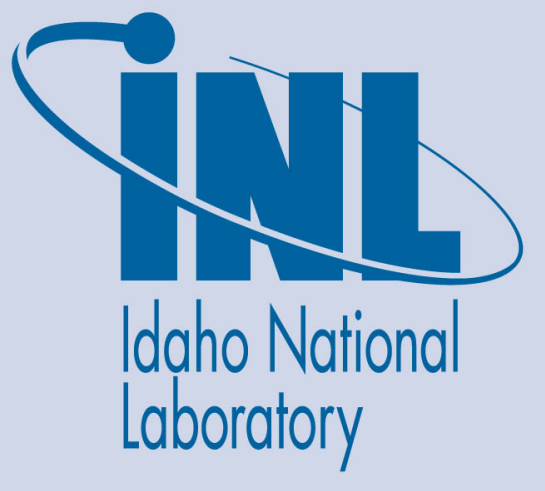

The INL is a U.S. Department of Energy National Laboratory operated by Battelle Energy Alliance 


\title{
Nuclear Technology Research and Development (NTRD) Technical Monthly June FY18
}

\author{
Various
}

August 2018

Idaho National Laboratory Idaho Falls, Idaho 83415

http://www.inl.gov

Prepared for the

U.S. Department of Energy

Under DOE Idaho Operations Office

Contract DE-AC07-05ID14517 


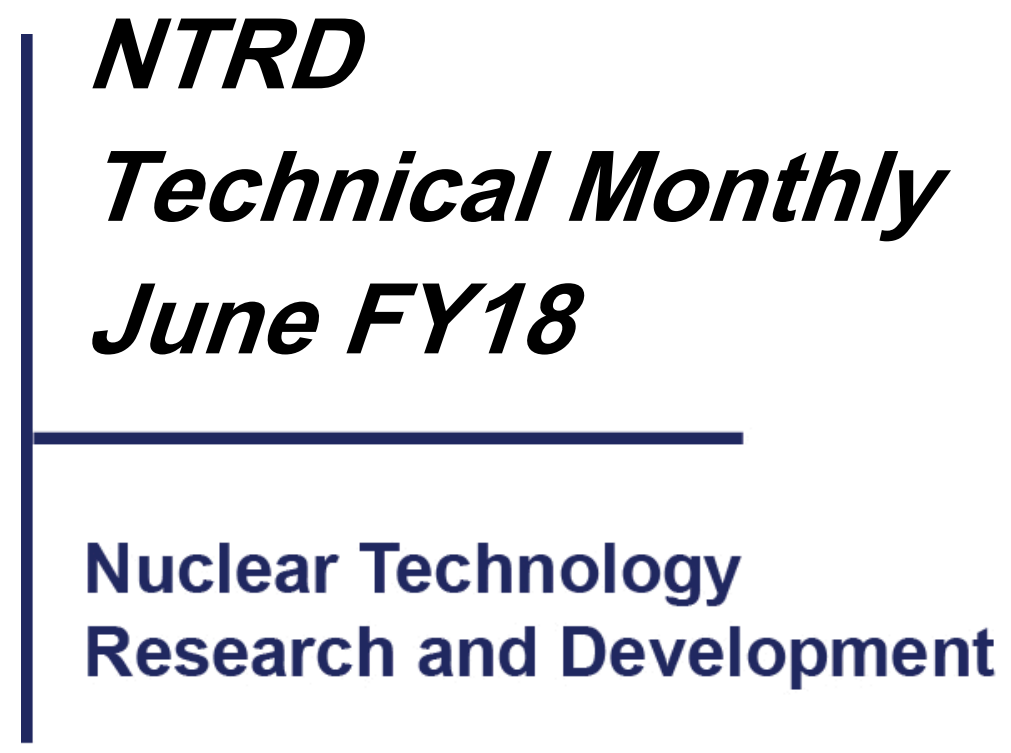

Prepared for U.S. Department of Energy

August 20, 2018

NTRD-PAC-2018-000477 INL/EXT-18-51175 



\section{DISCLAIMER}

This information was prepared as an account of work sponsored by an agency of the U.S. Government. Neither the U.S. Government nor any agency thereof, nor any of their employees, makes any warranty, expressed or implied, or assumes any legal liability or responsibility for the accuracy, completeness, or usefulness, of any information, apparatus, product, or process disclosed, or represents that its use would not infringe privately owned rights. References herein to any specific commercial product, process, or service by trade name, trade mark, manufacturer, or otherwise, does not necessarily constitute or imply its endorsement, recommendation, or favoring by the U.S. Government or any agency thereof. The views and opinions of authors expressed herein do not necessarily state or reflect those of the U.S. Government or any agency thereof. 



\section{CONTENTS}

ADVANCED FUELS CAMPAIGN..................................................................................... 1

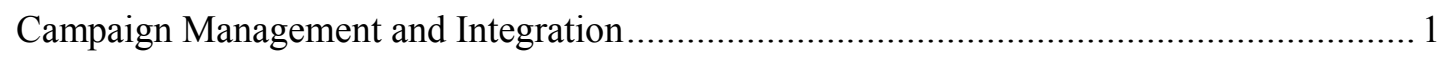

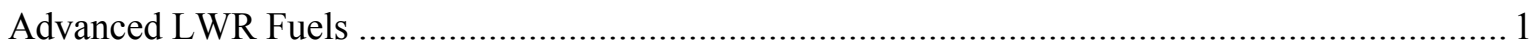

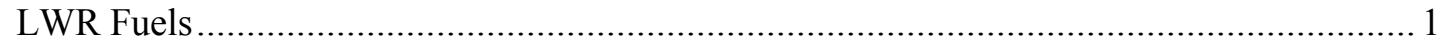

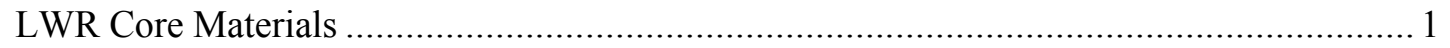

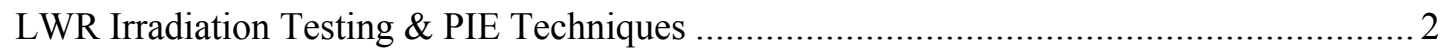

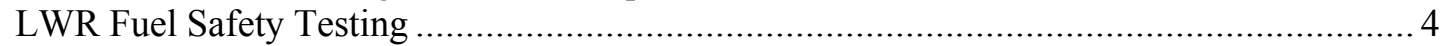

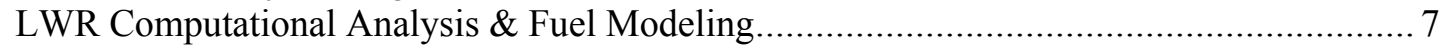

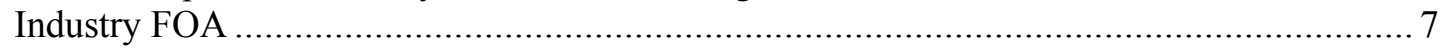

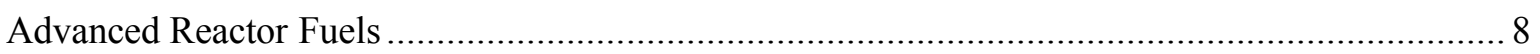

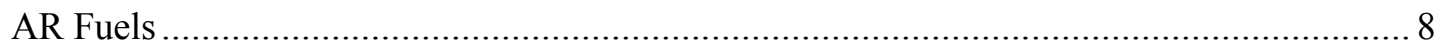

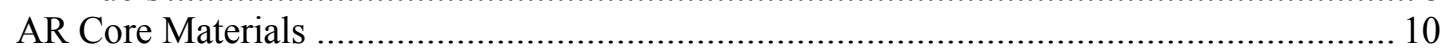

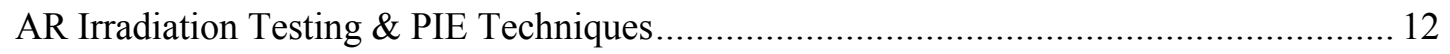

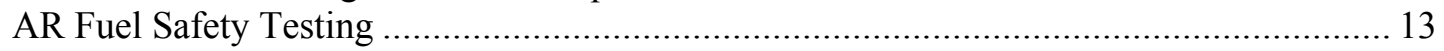

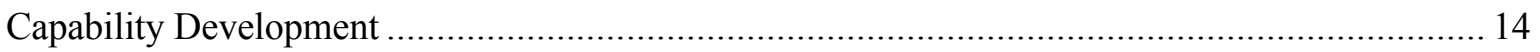

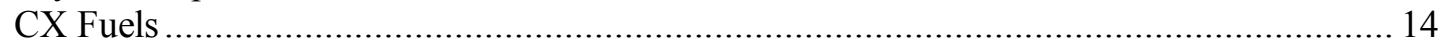

MATERIAL RECOVERY AND WASTE FORMS DEVELOPMENT .................................... 15

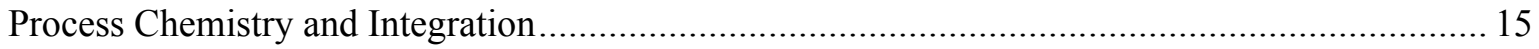

Sigma Team for Advanced Actinide Recycle ................................................................. 16

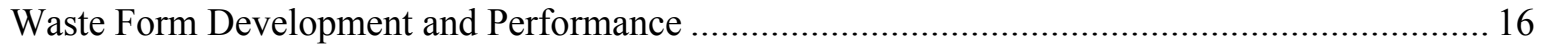

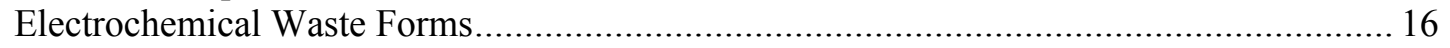

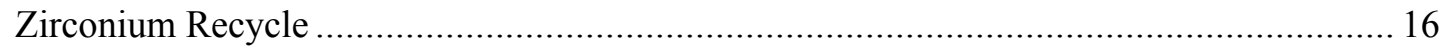

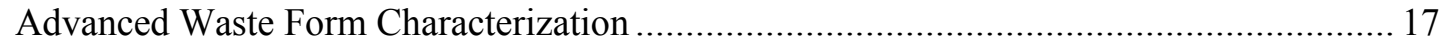

Domestic Electrochemical Processing ......................................................................... 18

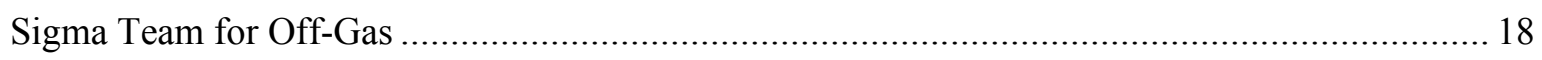

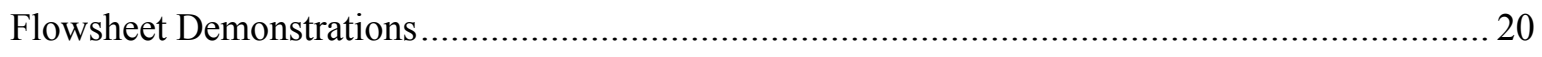

MPACT CAMPAIGN .............................................................................................................. 21

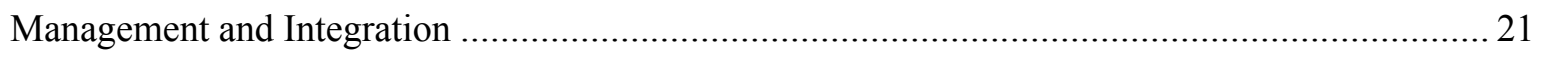

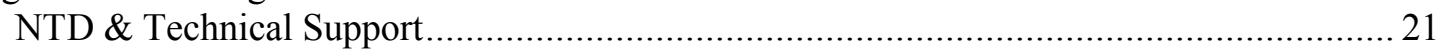

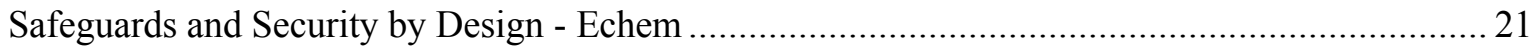

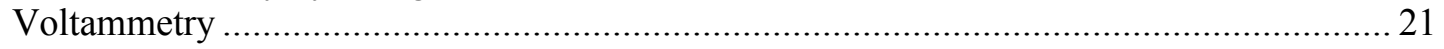

Sensor for Measuring Density and Depth of Molten Salt ........................................... 21

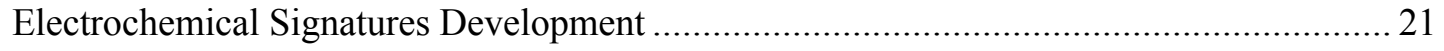

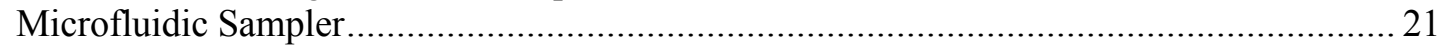

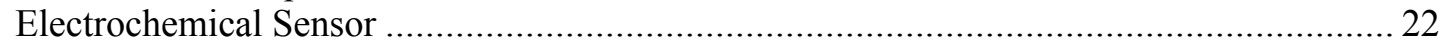

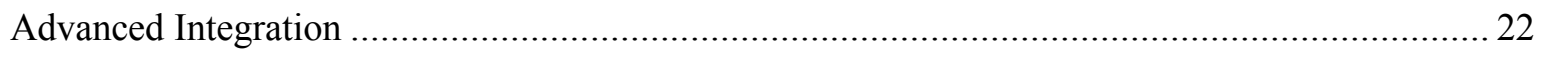

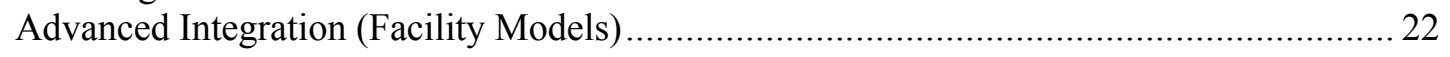

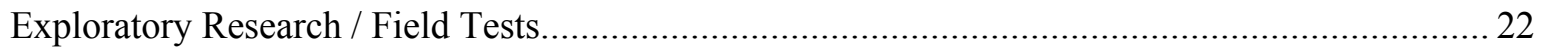

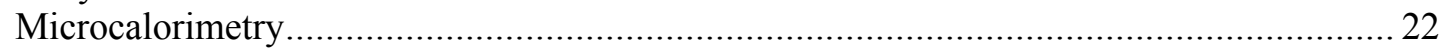

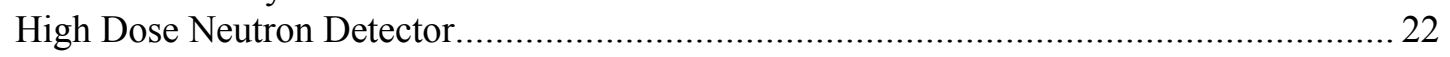

Fuel Cycle Options CAMpaign.............................................................................. 23 


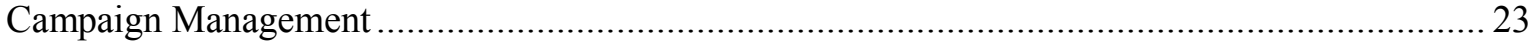

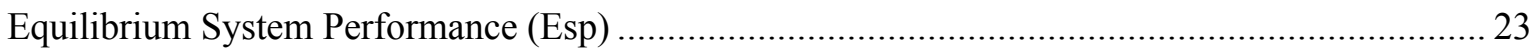

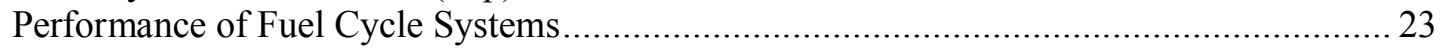

Economic Analysis Capabilities and Assessments ................................................... 24

Equilibrium System Performance (ESP) Tools Development ........................................... 24

Development, Development And Implementation Issues (DDII) ........................................... 24

Technology and System Readiness Assessment (TSRA) ..................................................2 24

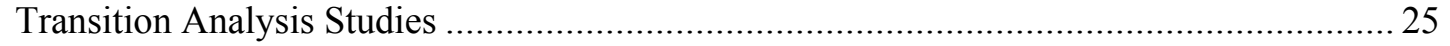

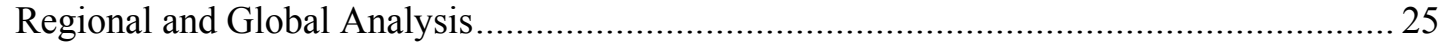

Development, Deployment, and Implementation Issues (DDII) Tools Development............ 26

JOINT FUEL CYCLE STUDY ACTIVITIES ............................................................................. 27

AFCI-HQ PROGRAM SUPPORT ............................................................................ 29

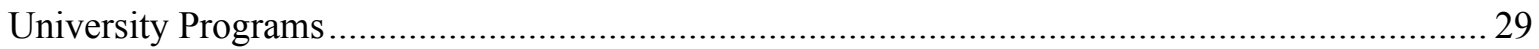

Universities engaged in Nuclear Technology research via URA programs since

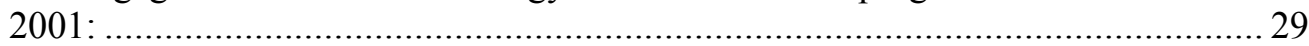

Innovations in Nuclear Technology R\&D Awards ........................................................... 29

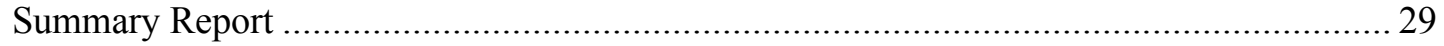




\section{FIGURES}

\section{Advanced Fuels CAMpaign}

Figure 1. Pictures showing UN kernels inside a molybdenum cup (top left), sealed capsules assembled prior to loading inside an irradiation target (bottom), and loading of the irradiation targets inside the basket that is loaded into HFIR (top right).

Figure 2. Photographs taken during the in-cell LOCA test showing (a) the temperature ramp and

(b) immediately following the water quench

Figure 3. Temperature and pressure histories for the in-cell LOCA test NA\#1 through full LOCA integral test sequence, including water quench at $800^{\circ} \mathrm{C}$.

Figure 4. Manipulator holding the North Anna \#1 fuel rod segment showing the burst region in front of the SATS system after the successful in-cell integral LOCA test.

Figure 5. The pressurization rate dependency of the failure strain of Sic/Sic composites tested with MBT. Failure strains were calculated using DIC methods from speckle-painted surfaces of the tube samples.

Figure 6. Gap closure simulations of Zircaloy (a) and FeCrAl (b). Because the gap closure behavior of $\mathrm{FeCrAl}$ fuel rods is much different than the Zircaloy, the gap remains open. These results show the sensitivity of the fuel to these fracture models without gap closure, emphasizing that calibration of these models is needed for the uniquely performing alloys with non-conventional fuel geometries.

Figure 7. Radiographic image of the segmented U-10Zr segmented rod. ........................................ 8

Figure 8. Current vacuum assisted casting hearth ready for benchtop testing. ..................................... 9

Figure 9 (1) figure combining phase-transition temperatures from fifteen publications, which are indicated by different symbols and (r) sections of two proposed U-Zr phase diagrams, with colored symbols indicating measured phase-transition temperatures for $\mathrm{U}-10 \mathrm{Zr}$ (wt $\%$ alloys). 10

Figure 10. New americium distillation furnace. 10

Figure 11. Average gas plenum temperatures in AF-SFR. 12

Figure 12. Internal gas pressure depending on locations of gas plenum in AF-SFR 12

Figure 13. CDF behavior depending on locations of gas plenum in AF-SFR. 13

\section{MATERIAL RECOVERY AND WASTE FORMS DEVELOPMENT}

Figure 1. Scanning electron microscopy showing the AgZ 1-7 sample before and after SPFT at $\mathrm{pH}_{(\mathrm{RT})} 11$ 


\section{NUCLEAR TECHNOLOGY RESEARCH AND DEVELOPMENT TECHNICAL MONTHLY JUNE FY18}

\section{AdVANCED FuELS CAMPAIGN}

\section{Campaign Management and Integration}

- [ORNL] Oak Ridge National Laboratory staff presented nine oral presentations and six posters on research supported by the Advanced Fuels Campaign at the Nuclear Fuels and Structural Materials for the Next Generation of Nuclear Reactors (NFSM). This biannual embedded topical, held at the 2018 Annual Meeting of the American Nuclear Society June 17-21 in Philadelphia, provides the opportunity for international leaders in the field to discuss the current status of nuclear materials research. The focus of the 2018 NFSM meeting was commercial deployment of accident tolerant nuclear fuels and other advanced concepts (A. Nelson).

\section{ADVANCED LWR FUELS}

\section{LWR Fuels}

- [LANL] Milestone report M3NT-18LA020201042, titled "Report on the thermophysical properties of the UO2 based ATF composites fabricated via field assisted sintering," was completed. In this work, SPS was used to sinter high density UO2-UBx composite fuel pellets ( $>90 \%$ TD). Preliminary assessment of the resulting microstructures has revealed a complicated system and indicates that the UO2 and UBx phases have reacted. Since the composite microstructures have not been straightforward and the thermal conductivity of UB2 and UB4 is not known in the literature, measurement of the UB2 and UB4 thermal conductivity emerged as an important first step towards understanding the composite system. Additionally, in light of the recently fabricated UO2UBx composites (this work) and other UO2 based composites such as the UO2-SiC, UO2-CNT and UO2-dimaond, produced at the University of Florida, some observations have been made on the potential of SPS for reliable improvements on the thermophysical properties of UO2 based composites. SPS was identified as a useful R\&D tool for the fabrication of materials that are difficult to sinter conventionally but are of interest due to their high thermal conductivity. However, in SPS the distribution of current flow within the sample and die body is unknown and in composites with high thermal conductivity phases, where the overall electrical conductivity can approach that of the punch and die set, controlling the temperatures within the sample can be difficult. This can lead to sample-to-sample variability as well as inhomogeneities in the microstructure which ultimately can adversely affect the thermal properties of the sample. Nonetheless, it has been demonstrated in the literature that under optimal SPS conditions UO2 based composites can be produced with thermophysical properties which are significantly improved relative to pure UO2. (E. Kardoulaki)

\section{LWR Core Materials}

- [LANL] Ion irradiations were performed on C26M tube samples using Fe ions to doses up to 15 dpa at $300^{\circ} \mathrm{C}$. Microstructure was characterized before and after irradiation using transmission electron microscopy (TEM). Results were compiled in a report to meet a level 3 milestone. Dislocation densities observed were similar to other FeCrAl alloys previously tested. (S. Maloy) 
- [LANL] Characterization was performed on tubes of C26M including EBSD and nanohardness testing. Data was compiled in a report to meet a level 3 milestone. Data shows a very uniform microstructure with some anisotropy along the tube extrusion direction from the tube drawing process. (S. Maloy)

- [LANL] Tensile and ring pull samples are being EDM machined from tubes of C26M to characterize the mechanical properties of new heats of this alloy. (S. Maloy)

- [ORNL] Mechanical testing of additively manufactured HT-9 cladding using digital image correlation (DIC) techniques was completed on the as-fabricated and post-fabrication heat treated specimens. DIC provides the ability to determine local deformation effects and true stress-strain correlations. Results show limited deformation localization in the as-printed and treated components with the as-printed components having significant strength compared to wrought HT9 variants. Results have been summarized with previous characterization efforts in a pre-draft manuscript. (K. Field/N. Sridharan/M. Gussev)

- [ORNL] Manuscript preparation is in process on the yttrium effects on the grain stability of ferritic alloys (Gen. II FeCrAl alloys and two additional model alloys) at high temperatures. The mechanism of the grain stability observed from different ferritic alloys annealed at $1200^{\circ} \mathrm{C}$ is to be discussed, by coupling the detailed characterization of the yttrium distribution as Fe17Y2-type particles and grainboundary segregation. (Z. Sun, Y. Yamamoto)

- [ORNL/Framatome] A review of Generation I FeCrAl cladding properties between ORNL and Framatome was completed to evaluate the viability of using FeCrAl alloys in a PWR test geometry. Plans are to publish the findings, providing direct input into the FeCrAl cladding handbook. (K. Field/ J. Bischoff)

- [ORNL] UC Davis PhD candidate Can Agca arrived in June to conduct research on the thermodynamics of the Fe-Cr-Al-O system. Ferritic FeCrAl alloys are candidate accident tolerant cladding materials. There is a paucity of data concerning the melting behavior for FeCrAl and its oxides. Analysis tools have therefore had to utilize assumptions for simulations using FeCrAl cladding.

The proposed research aims to develop integrative workflow that can enhance thermodynamic understanding of $\mathrm{FeCrAl}$ oxides in the form of ionic solid solutions by combining experimental, computational, and theoretical resources at ORNL and UC Davis. The partnership leverages the strengths in neutron diffraction and CALPHAD (CALculation of PHAse Diagrams) modeling at ORNL with the expertise and extensive experience of UC Davis in calorimetry and thermodynamic theory. Key physics based on experiments will be captured by models developed using the CALPHAD method. The approach is applied to the Fe-Cr-Al-O system high temperature phase space in the vicinity of spinel and liquid to provide critical parameters, like melting behavior, in order to predict phenomena such as the onset of relocation in the core. (J. McMurray)

- [ORNL] The handbook of properties of SiC cladding was updated during this period. The new data added includes statistical tensile properties (proportional limit stress and ultimate strength), hydrothermal corrosion behavior of environmental barrier coating on $\mathrm{SiC}$, accurate temperature- and dose-dependent swelling, and anisotropic elastic properties (Young's modulus, shear modulus, and Poisson's ratio) of SiC composite tube. Further updates on the handbook will be conducted during the next period, especially on thermal properties of SiC cladding. (T.Koyanagi, Y.Katoh)

\section{LWR Irradiation Testing \& PIE Techniques}

- [INL] The ATF-2 experiment was installed in the Advanced Test Reactor (ATR) Loop 2A-C on May 30, 2018 and irradiation began at full power on June 12, 2018. The experiment reached 12 effective 
full power days of irradiation prior to the ATR shutdown on June 24, 2018 due to a fire in the control room. Plans for recovery and restart are underway. (G. Hoggard)

- [INL] Additional analysis was performed on gamma spectrometry scans collected on ATF capsules containing $\mathrm{UO} 2-\mathrm{FeCrAl}$ rodlets, $\mathrm{UO} 2-\mathrm{FeCrAl}$ interactions, and $\mathrm{U} 3 \mathrm{Si} 5 \mathrm{FeCrA1}$. From this data, it is generally possible to evaluate fuel position, burnup gradients across the fuel, and some other irradiation conditions. For example, the burnup across the U3Si5 fuel varies by about $50 \%$ from the lowest burnup to the highest burnup portion of the fuel and a similar trend is observed in the UO2FeCrAl interaction test. More detailed gamma spectrometry scans will be performed after the rodlets are removed from their capsules. (J. Harp)

- [ORNL] The Level 2 milestone M2NT-18OR020203041,"Irradiation of Miniature Fuel Specimens in the High Flux Isotope Reactor (HFIR)," was completed on June 28, 2018. Two irradiation targets containing a variety of uranium nitride fuel kernels with and without TRISO coatings were inserted into HFIR during cycle 480 . The milestone report summarizes the experiment facility design and analysis, as well as the assembly of the first set of experiments. This flexible irradiation vehicle will enable high-throughput separate effects irradiation testing that can cover a wide range of fuel performance variables. The small size of the fuel specimens simplifies the design, analysis, and postirradiation evaluations. Post-irradiation examination will provide fundamental data on the stability and behavior of advanced fuels as a function of temperature and burnup. (C.M. Petrie, J.R. Burns, R.N. Morris, K.R. Smith, A.G. Le Coq, K.A. Terrani)
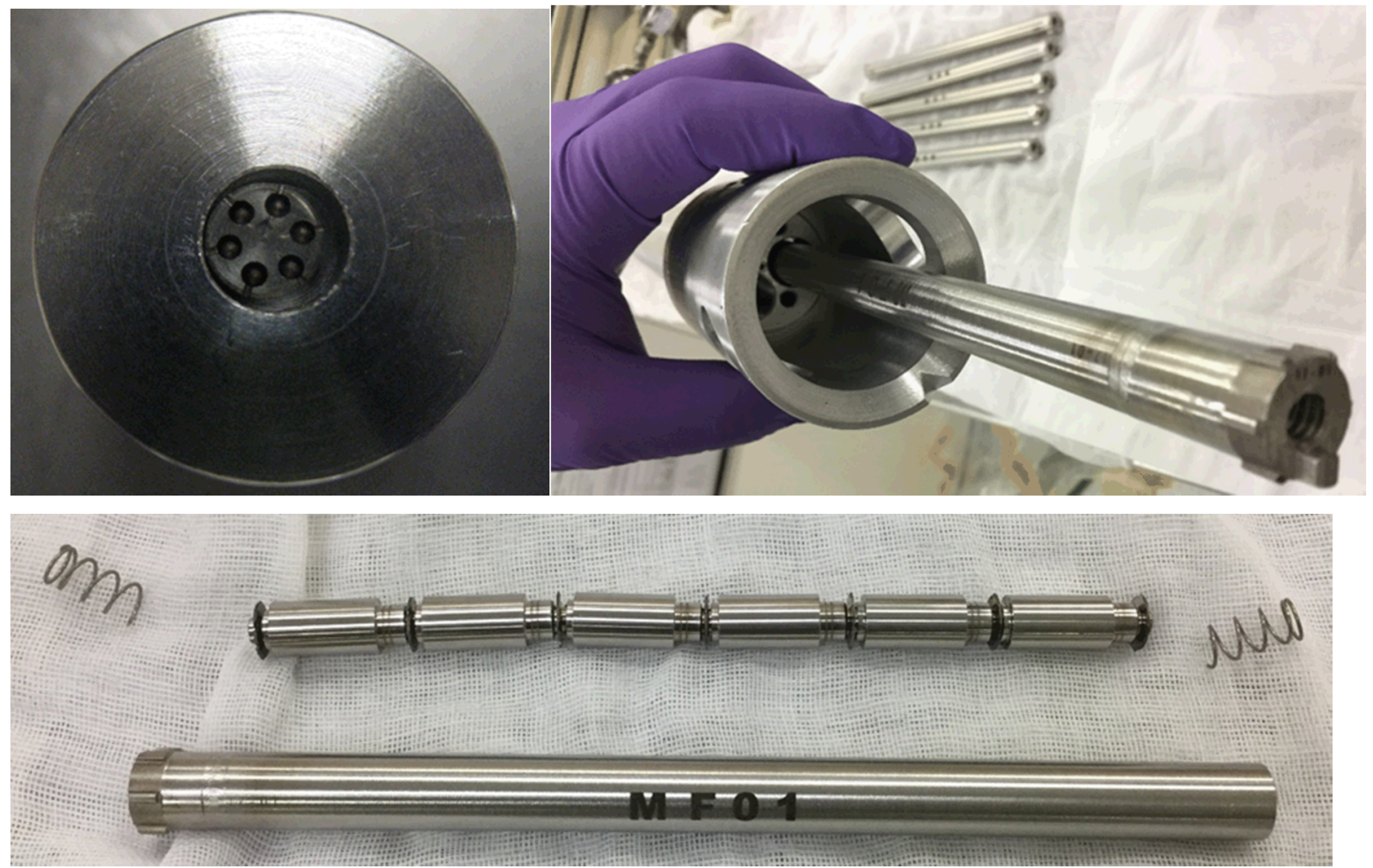

Figure 1. Pictures showing UN kernels inside a molybdenum cup (top left), sealed capsules assembled prior to loading inside an irradiation target (bottom), and loading of the irradiation targets inside the basket that is loaded into HFIR (top right). 
- [ORNL] All materials for the HFIR irradiation of advanced cladding materials including additive manufactured 9/12Cr alloys, ODS variants, and wrought $\mathrm{FeCrAl}$ alloys are undergoing dimensional inspection to provide insertion into the HFIR core by the end of the fiscal year. (K. Field/A. Le Coq)

\section{LWR Fuel Safety Testing}

- [INL] SETH capsule and associated components fabrication is complete. This is the innermost piece of hardware that will hold the test specimen. Also, weld preparations/test welds for the primary pipe are in process and welding of the primary pipes is expected to occur on schedule. The primary pipe is the piece of hardware that provides the primary experiment containment. (D. Dempsey)

- [INL] DAS and Experiment Instrument Panel (EIP) panels are complete and installed. The conduit is installed and cables have been run between DAS and EIP. Power to the DAS cabinet is run. Monitors in the Control Room were installed. Wiring of cables in the EIP has commenced. The Acceptance Test Plan is in review (eCR initiated 6/25/2018) with deadline of 7/12/2018. (J. Schulthess/T. Pavey)

- [ORNL] The Level 2 Milestone M2NT-18OR020204031 titled, "Issue report on in-cell re-fabrication of irradiated rods and LOCA testing," was successfully completed on June 27, 2018. Building on the July 2017 in-cell installation and demonstration of the Severe Accident Test Station (SATS) this year, a high burnup commercial spent fuel segment was re-fabricated into a pressurized test train for fuel safety testing. A report describing the in-cell re-fabrication capabilities, assembly of the loss-ofcoolant-accident (LOCA) test train, and integral LOCA test was provided. The in-cell integral LOCA test (Figure 2) was performed by subjecting the fuel segment to a steam environment, internal pressure, temperatures up to $1200^{\circ} \mathrm{C}$, and water quench (Figure 3). The successful in-cell refabrication and integral LOCA test (Figure 4) establishes the SATS as a vital tool for out-of-pile integral fuel safety testing of nuclear fuels and, more specifically, accident tolerant fuel (ATF) concepts by subjecting them to conditions relevant to design basis accident (DBA) and beyond design basis accident (BDBA) scenarios. (A. Raftery, Y. Yan, T. Smith, Z. Burns, K. Terrani, K. Linton) 

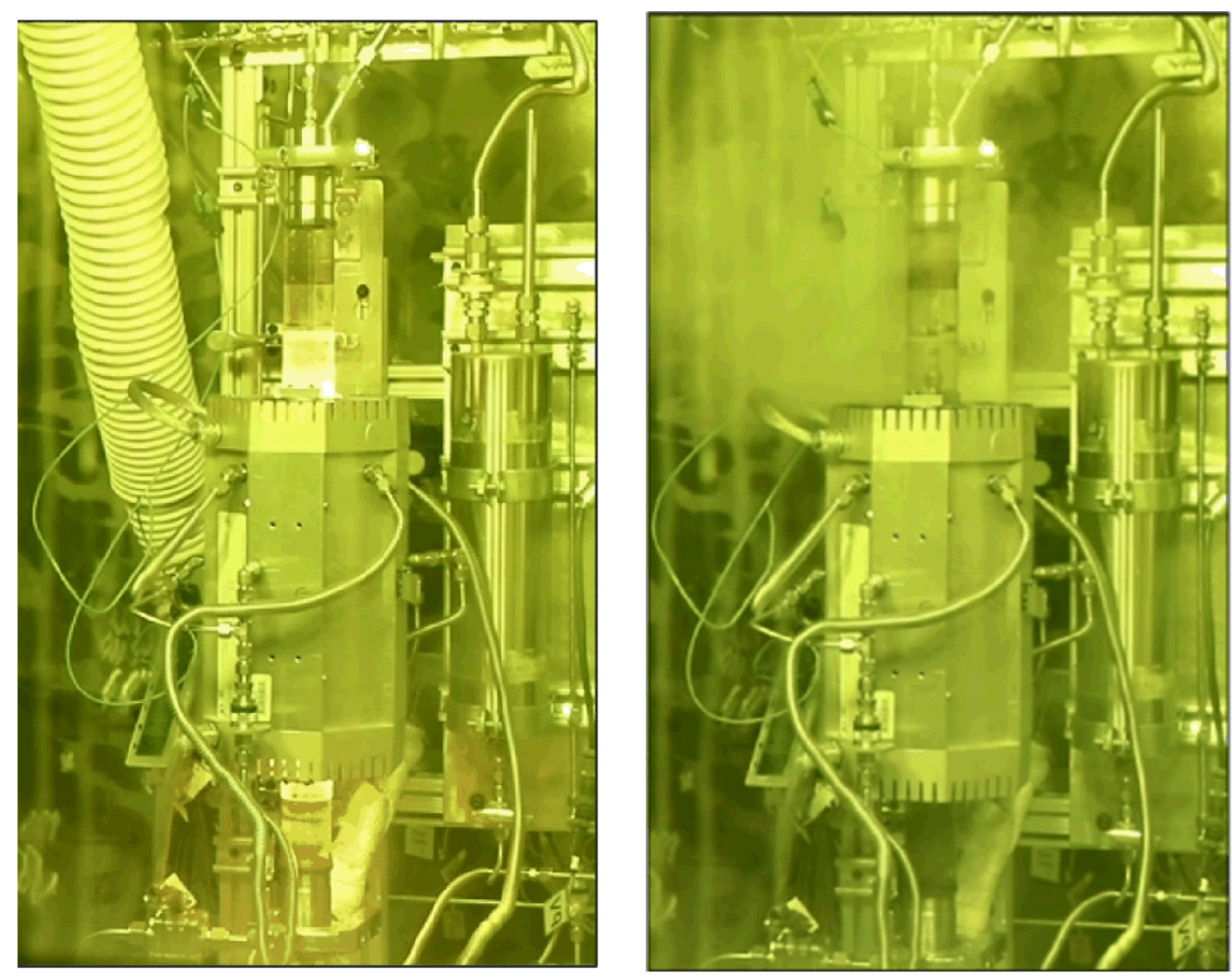

Figure 2. Photographs taken during the in-cell LOCA test showing (a) the temperature ramp and (b) immediately following the water quench.

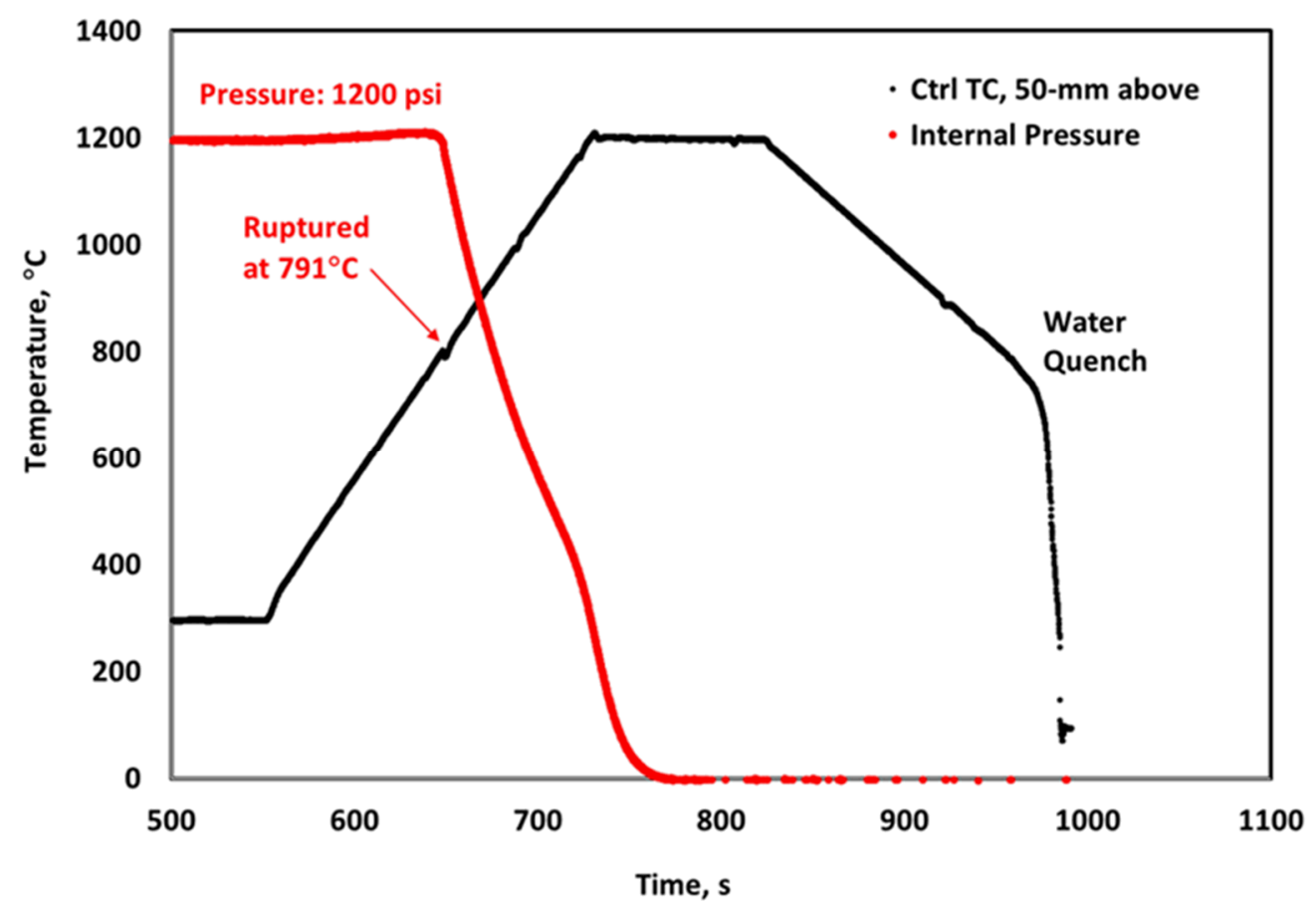

Figure 3. Temperature and pressure histories for the in-cell LOCA test NA\#1 through full LOCA integral test sequence, including water quench at $800^{\circ} \mathrm{C}$. 


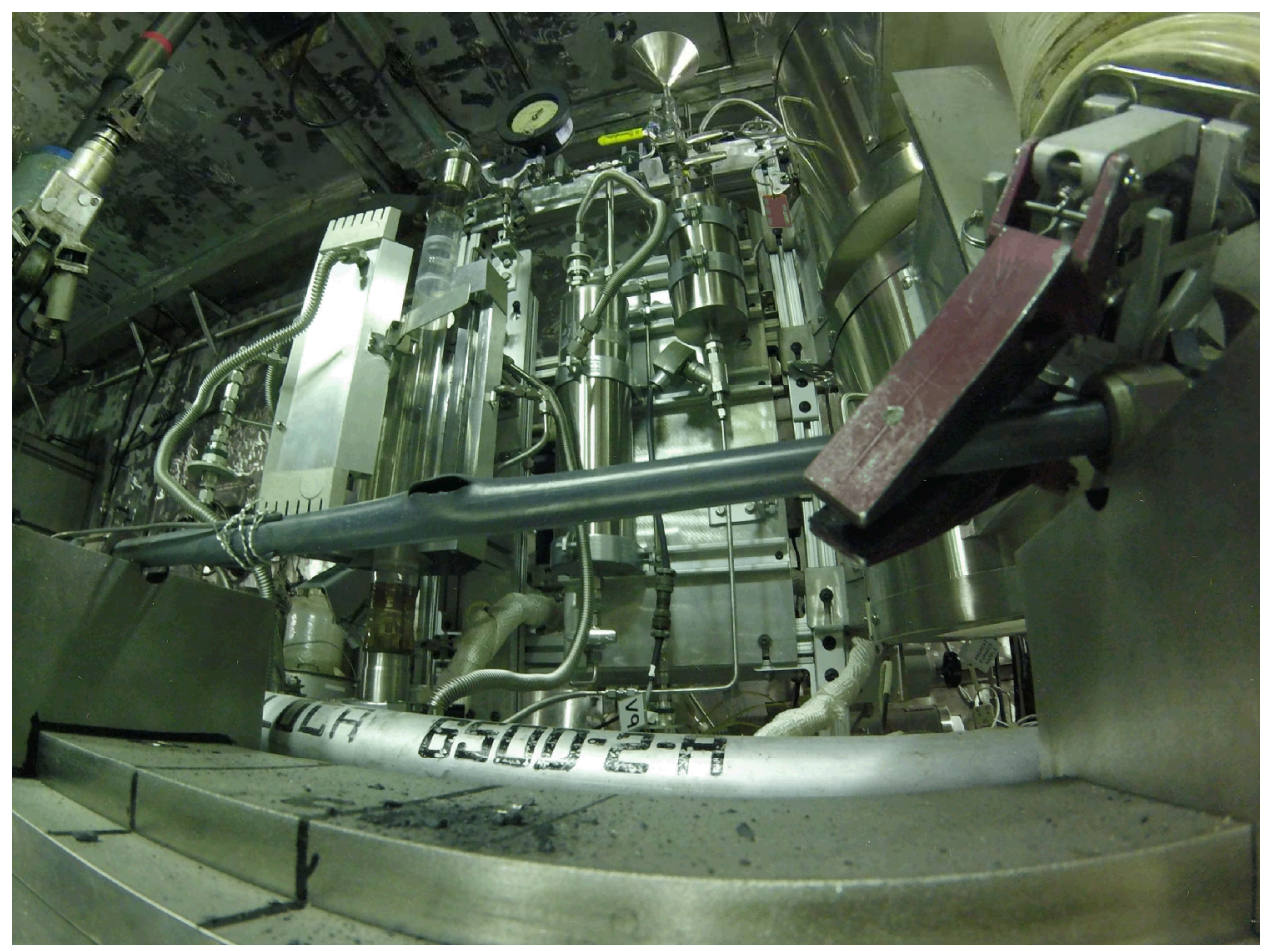

Figure 4. Manipulator holding the North Anna \#1 fuel rod segment showing the burst region in front of the SATS system after the successful in-cell integral LOCA test.

- [ORNL] A journal article is under review in Annals of Nuclear Energy. The paper describes the newly developed digital image correlation system and the novel advanced optical system for the transient mechanical test capability. (M. N. Cinbiz, M. Gussev, K. A. Terrani, K. Linton)

- [ORNL] A draft journal article is being prepared for submission to the Journal of Nuclear Materials. This paper investigates the effect of strain-rate on the failure strain of $\mathrm{SiC} / \mathrm{SiC}$ composites under pellet-clad interaction loading (Figure 5). The paper also informs potential safety limits for the planned TREAT experiments for SiC/SiC composites. (M. N. Cinbiz, Y. Katoh, T. Koyagani, K. A. Terrani, N. R. Brown)

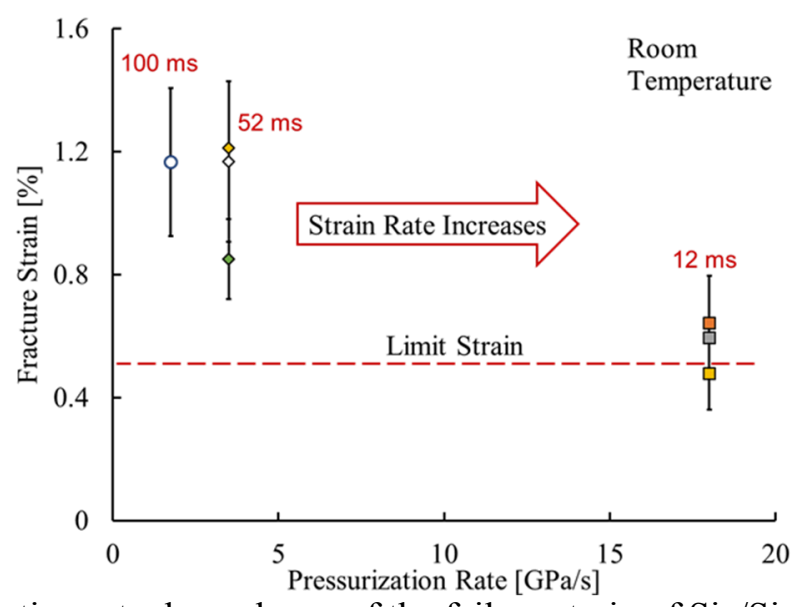

Figure 5. The pressurization rate dependency of the failure strain of Sic/Sic composites tested with MBT. Failure strains were calculated using DIC methods from speckle-painted surfaces of the tube samples. 
- [ORNL] High-temperature testing capability has been set-up for MBT. Long-term heat-treated generation-one (Gen-I) and as-drawn Gen-II tube samples have been tested at $250^{\circ} \mathrm{C}$ to simulate the pellet-cladding mechanical interaction relevant conditions for reactivity-initiated accidents. (M. N. Cinbiz, R. Lowden Jr., N. Brown, K. A. Terrani, K. Linton)

\section{LWR Computational Analysis \& Fuel Modeling}

- [ORNL] The Level 3 milestone M3NT-18OR020205031 was completed on June 28, 2018. A report titled, "Analysis of FeCrAl cladding and UO2 fuel including discrete and smeared cracks, and fuel relocation," was provided describing the use of the BISON fuel performance code to analyze the performance of $\mathrm{FeCrAl}$ cladding fueled with uranium oxide pellets. This report builds upon prior work using BISON to analyze the FeCrAl-based accident tolerant fuel concept, and which has shown that the mechanical behavior of the cladding after closure of the fuel - cladding gap is very sensitive to the fuel mechanics. In this work, we have specifically investigated several different methods for the incorporation of fuel fracture, which is an important mechanism of the diametral expansion, into the BISON fuel performance code. The results of our analysis do indicate due to the much lower creep rates of FeCrAl (relative to $\mathrm{Zr}$-alloys, Figure 6), that the impact of varying fracture models for $\mathrm{FeCrAl}$ cladding is much less sensitive than the case of conventional Zr-alloy rods. Future work remains to incorporate mechanistic models of crack healing, which is an important aspect of the fracture mechanics affecting the re-cohesion or re-sintering of the cracked surface. We believe development and implementation of a crack healing model can produce better agreement of the model predictions with experimental results. Future efforts will also begin to focus on incorporating aspects of fuel fracture into the fission gas release models. (R. Sweet, A. Nelson, B. Wirth)
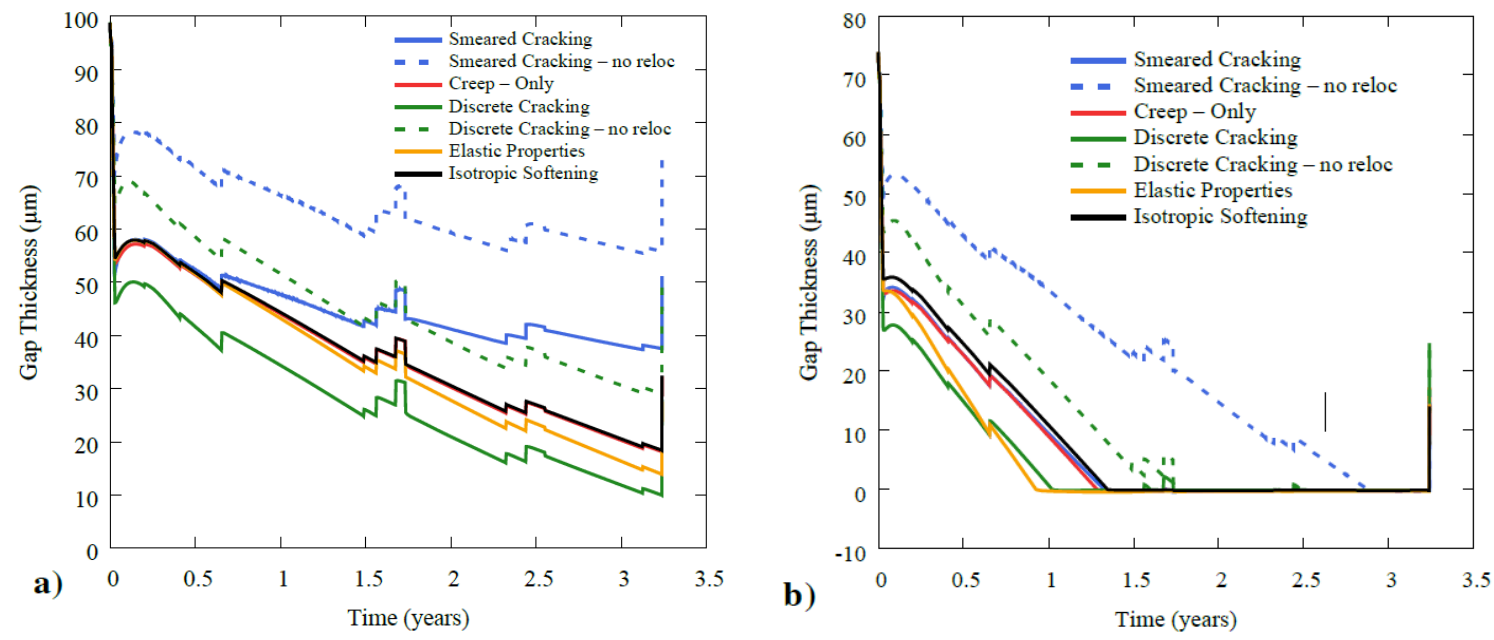

Figure 6. Gap closure simulations of Zircaloy (a) and FeCrAl (b). Because the gap closure behavior of FeCrAl fuel rods is much different than the Zircaloy, the gap remains open. These results show the sensitivity of the fuel to these fracture models without gap closure, emphasizing that calibration of these models is needed for the uniquely performing alloys with non-conventional fuel geometries.

\section{Industry FOA}

- $\quad$ [INL] Dry run testing using DU materials was completed. Analytical Laboratory method development and validation was completed for all fuel pellet specification requirements. Review of the Fuel Pellet Manufacturing and Quality Plan was completed. PLN-5609, the U3Si2 Grain Size and Phase Quantification Test Plan was issued. (S. Martinson) 
- [ORNL/GE] Recent findings on FeCrAl claddings including the design of FeCrAl alloys and the corrosion of FeCrAl alloys were presented at the American Nuclear Society (ANS) Nuclear Fuels and Structural Materials (NFSM) embedded topical by ORNL and GE investigators. Data presented will be included in the upcoming handbook update. (K. Field/D. Zhang/R. Rebak)

\section{ADVANCED REACTOR FUELS}

\section{AR Fuels}

- [INL] Segmented DU-10Zr and DU-6Zr extrusion was carried out previously using new extrusion hardware. The segmented U-10Zr extruded samples have been sectioned for ease of handling in preparation for more detailed characterization. The first characterization performed was radiography of the entire extruded length. The radiograph is shown in Figure 7. From these it can clearly be seen that the extrusion went well and the segmented billet did not show any large discontinuities. The segment interfaces are not distinguishable in the radiograph.

Last month an ultrasonic inspection technique for inspection the sodium bond of loose foil fuel chemical cladding interaction barrier was shown to be feasible. To continue this development additional rodlet will be fabricated varying barrier thickness, bonding methods, and number of barrier layers. The sample rodlet fabrication has been initiated and the bottom welds performed). (R. Fielding)

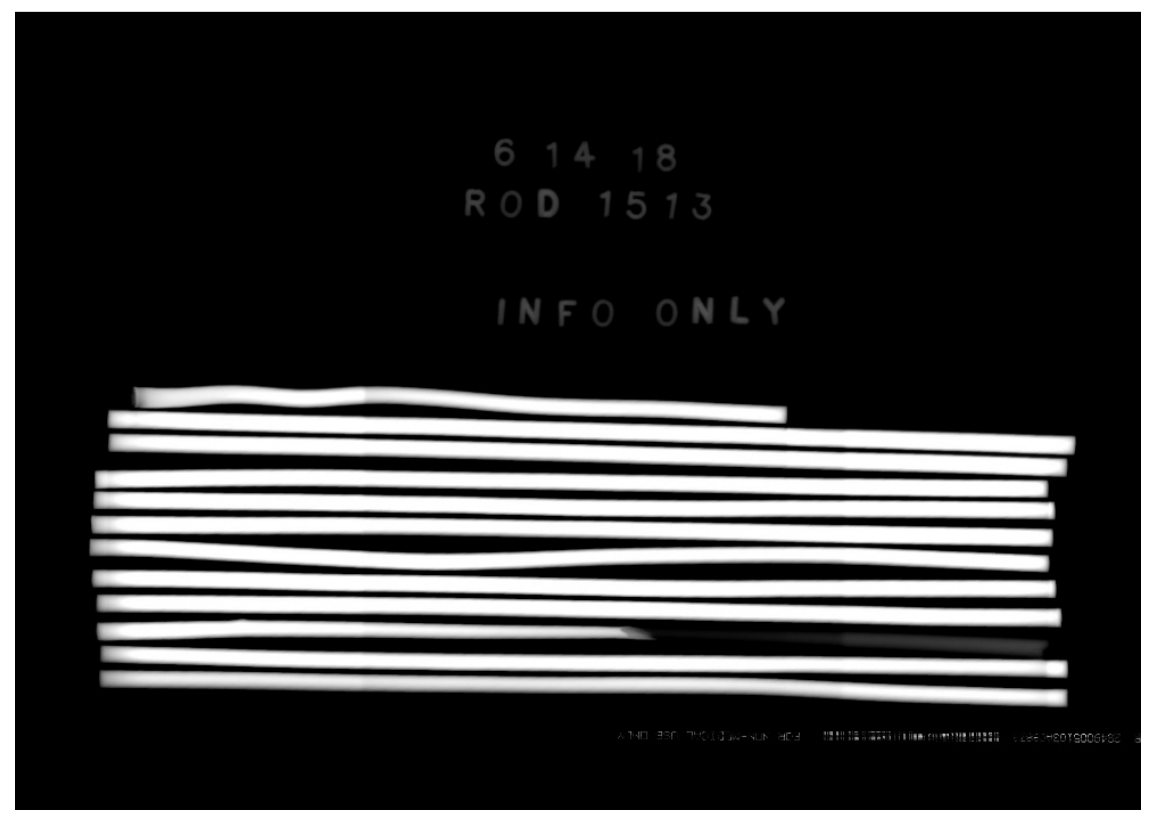

Figure 7. Radiographic image of the segmented U-10Zr segmented rod.

- $\quad$ INL] As part of a new test design, interest has been expressed in fuel that is much smaller in diameter than the standard $4.2 \mathrm{~mm}$ diameter. As the diameter of fuels becomes small, casting become more difficult. The current arc casting process is gravity driven, as the casting diameter becomes smaller, it becomes more difficult to overcome the surface tension of the material. In addition to surface tension as the fuel mass decreases, the length the fuel will flow before freezing off decreases because the size of the casting hearth is set by the equipment design. To overcome these issues, a vacuum assisted casting hearth has been designed that can be incorporated into the standard arc casting furnace currently in use. The original design was slightly over complicated. A new system has been designed and fabricated and is currently ready for bench top testing. Figure 8 shows the current 
system ready for benchtop testing. The system consists of the modified casting hearth, a hand operated vacuum pump, and a length of hose connecting these hearth and vacuum pump/chamber. (R. Fielding)

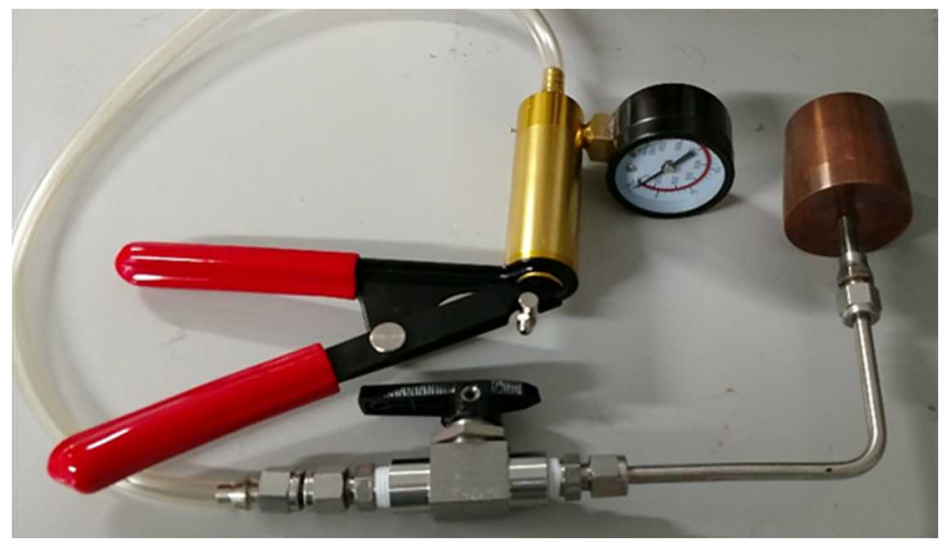

Figure 8. Current vacuum assisted casting hearth ready for benchtop testing.

- [INL] Work continues to finalize additional information that will be added to this year's edition of the Metal Fuels Handbook. Figure 9 (left) combines phase-transition temperatures from fifteen publications, which are indicated by different symbols. Most of these publications appeared after the latest experimentally based phase diagram in 1989. The quality of the individual measurements varies, but it is nonetheless possible to recognize consistent patterns that require explanation.

Figure 9 (right) includes sections of two proposed U-Zr phase diagrams, with colored symbols indicating measured phase-transition temperatures for $\mathrm{U}-10 \mathrm{Zr}(\mathrm{wt} \%)$ alloys.

Comparisons between the phase diagrams and the phase-transition temperatures suggest that temperatures near $\sim 600^{\circ} \mathrm{C}$ are probably related to the transitions at the upper temperature limit of $\delta$ $\mathrm{UZr} 2$ (" $\delta$ " in the phase diagrams), and temperatures between $\sim 660$ and $715^{\circ} \mathrm{C}$ may be related to transitions between $\alpha-\mathrm{U}, \beta-\mathrm{U}$, and $\gamma 1$. The two transitions above $750^{\circ} \mathrm{C}$ are both in compositions with low $\mathrm{Zr}$ contents and probably represent the transition between $\beta-\mathrm{U}$ and $\gamma$. The pattern in which alloys with more than $\sim 60$ at $\% \mathrm{Zr}$ have only one transition is misleading because this data was collected to identify the maximum temperature of stability for $\delta$ - $\mathrm{UZr} 2$ and the possibility of higher-temperature transitions was not investigated.

The left figure shows a pattern in which compositions with less than $\sim 22$ at $\% \mathrm{Zr}$ have two transitions between $\sim 660$ and $725^{\circ} \mathrm{C}$, with the temperature difference between the transitions decreasing as $\mathrm{Zr}$ content increases from $\sim 5$ to 20 at $\% \mathrm{Zr}$. This pattern is not obviously consistent with either of the proposed phase diagrams and serves as added evidence that further investigations of the U-Zr phase diagram are needed. (C. Papesch) 


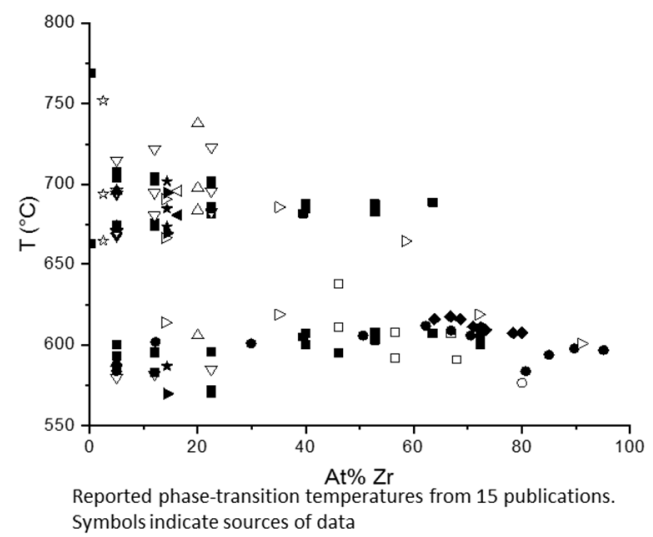

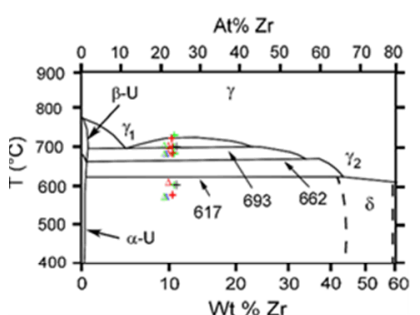

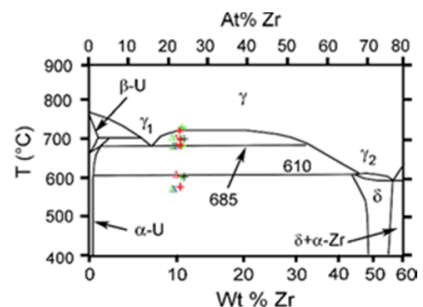

Portions of the phase diagrams of Sheldon and Peterson (1989) and Rough, Bauer, and colleagues (several publications between 1955 and 1959). The Sheldon and Peterson phase diagram is widely accepted, although Ahn and colleagues have recently pointed out that the phase diagram of Rough and colleagues is more consistent with their phase-transition measurements. Neither of these phase diagrams is obviously consistent with the data in the top figure for alloys with less than w22 NuclearTechnology

Figure 9 (1) figure combining phase-transition temperatures from fifteen publications, which are indicated by different symbols and (r) sections of two proposed U-Zr phase diagrams, with colored symbols indicating measured phase-transition temperatures for $\mathrm{U}-10 \mathrm{Zr}$ ( $\mathrm{wt} \%$ alloys).

- [INL] The new americium distillation furnace was received and conditioned to coat the heating coils. This furnace is a replacement for the distillation furnace which stopped operating in January. The arrival and conditioning of this furnace will allow for the restart of americium distillation experiments which have been on hold since the last furnace failed. (L. Squires)

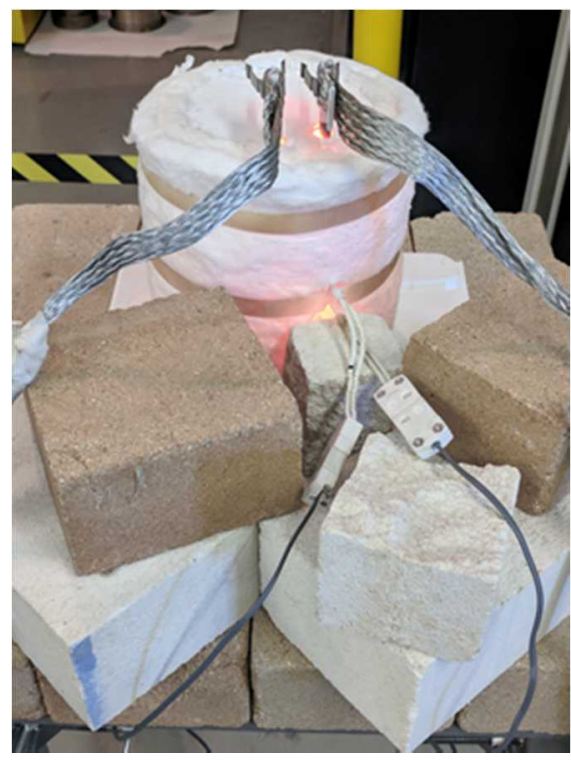

Figure 10. New americium distillation furnace.

\section{AR Core Materials}

- $\quad$ [PNNL] Four M3 milestone reports were completed and submitted - M3NT-PN020302027, "APTbased Comparison of Neutron and Ion Irradiated MA957," M3NT-18PN020302029, "Report on Accelerator-to-Accelerator Differences in Microstructural Evolution," M3NT-18PN020302028, "Report on 14YWT Microstructural Observations," and M3NT-18PN020302022, "Mechanical Properties and Microstructure of Three New 9Cr Steels." These substantial reports provided baseline microstructure observations and properties on ferritic steels for cladding applications and detailed microstructural analysis after neutron and ion irradiation exposures. 
- [PNNL] Preparation for ion irradiations of 14YWT at Texas A\&M University in support of Milestone M3NT-18PN020302023 and HT-9 for Milestone M3NT-18PN020302024 is underway. (M. Toloczko)

- [LANL] A talk was presented by Ben Eftink at the ANS meeting on nitrogen effects in HT-9 alloys. Data shows a higher density of dislocation loops in high nitrogen in comparison to low nitrogen alloys of HT-9. (S. Maloy)

- [ORNL] A talk titled, "Development of the Nanostuctured Ferritic Alloy OFRAC (Fe-12CrMoTiNb) for Fast Reactor Advanced Fuel Cladding," was given at CIMTEC 2018: 8th Forum of New Materials in Perugia, Italy on June 10-14, 2018. There were many questions and follow-up discussions regarding this new nanostructured ferritic alloy, especially with regard to the successful fabrication of the $1,780 \mathrm{~mm}$ long and $8.5 \mathrm{~mm}$ diameter thin wall $(0.5 \mathrm{~mm})$ tube. A second talk titled "History and Outlook of ODS/NFA Ferritic Alloys for Nuclear Applications," was presented at the American Nuclear Society 2018 Annual Meeting in Philadelphia, PA on June 17-21, 2018. The talk covered the early development of ODS alloys for fast reactor fuel cladding and the development progress of 14YWT in terms of mechanical properties, radiation tolerance and fabrication of thin wall tubing and joining by solid state friction stir welding. (D. Hoelzer)

- [ORNL] Three Zoz Simoloyer high-kinetic energy ball mills (two CM01 and the CM08) were relocated to a new laboratory. Cooling water, vacuum and gas supply lines and a power transformer were installed. The relocation of the ball mills is significant, since there will be no restrictions on when the ball mills can be operated, which hindered research utilizing these ball mills in the former laboratory location. (D. Hoelzer)

- [PNNL] As part of the program to advance the technology associated with fabricating tubing from difficult-to-fabricate materials, the PNNL rolling mill is being modified so that it can perform pilgering of tubes. This will establish a unique $R \& D$ capability within the DOE complex. The rollers needed to perform the pilgering process are currently being machined by Precision Products with a six week completion schedule. It is anticipated that the machined pilgering rollers will be in the lab and ready to install in the rolling mill sometime around the end of July. To ensure that the installation proceeds as quickly and efficiently as possible, a check list of all items needed to complete the installation in preparation for the first pilgering runs has been developed. This check list will be used to guide and coordinate the parts of the lab that are necessarily involved in the setup and installation process, including programming the electronics on the rolling mill as needed for pilgering. (R. Omberg)

- [ORNL] The database used to generate the submitted milestone, M3FT-17OR020203034, was compiled and will be transmitted to LANL for further analysis providing detailed tomographic reconstructions of HT-9 after high dose neutron irradiations in the FFTF. High fidelity tomographic reconstructions are needed to determine the influence of radiation-induced/enhanced microstructural features on the radiation tolerance of HT-9 for high dose cladding applications. (K. Field)

- [PNNL] Fracture resistance (J-R) testing at 25, 300, and $600^{\circ} \mathrm{C}$ was completed for the original and $\mathrm{N}$-doped HT-9 steels in various quenched and tempered conditions. The final results of this fracture testing campaign will be used to determine a few thermomechanical processing routes that are optimized for significantly improved fracture toughness and strength in the HT-9 steels. Approximately $60 \mathrm{~J}$-R tests have been carried out for 10 different quenching and tempering conditions, and more testing at intermediate temperatures will be continued to obtain complete temperature dependence curves. (T.S. Byun) 


\section{AR Irradiation Testing \& PIE Techniques}

- [ANL] A 1000 MWth annular-fueled sodium-cooled fast reactor (AF-SFR) concept using low smeared density (55\%) annular fuels was developed over the last few months. The primary purpose of the AF-SFR was to achieve a high burnup ( $20 \%)$ using the low smeared density annual fuels. The fuel performance such as the closing of central void hole by irradiation induced swelling, peak temperatures of cladding and fuel, et al, were evaluated using the BISON code with adopted correlations. The advantages of adopting a lower plenum design with the annular fuels were investigated in June. Figure 11 shows the average plenum temperatures in several assemblies in the AF-SFR. For the same core design and operating conditions, the location of gas plenum was simply changed. The lower plenum design has about $100^{\circ} \mathrm{C}$ lower average gas plenum temperature than the conventional upper plenum design, which gives about $2 \mathrm{MPa}$ lower internal gas pressure at discharge burnup (see Figure 12). Owing to the both lower temperature and plenum, the lower plenum design is capable of lowering the CDF (see Figure 13). (N. Stauff and Y. Miao)

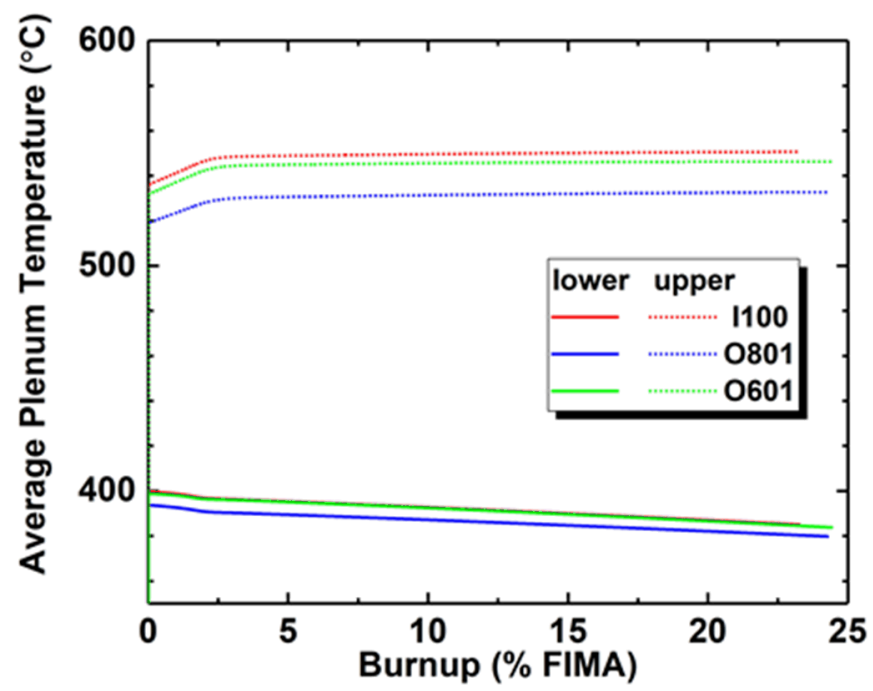

Figure 11. Average gas plenum temperatures in AF-SFR.

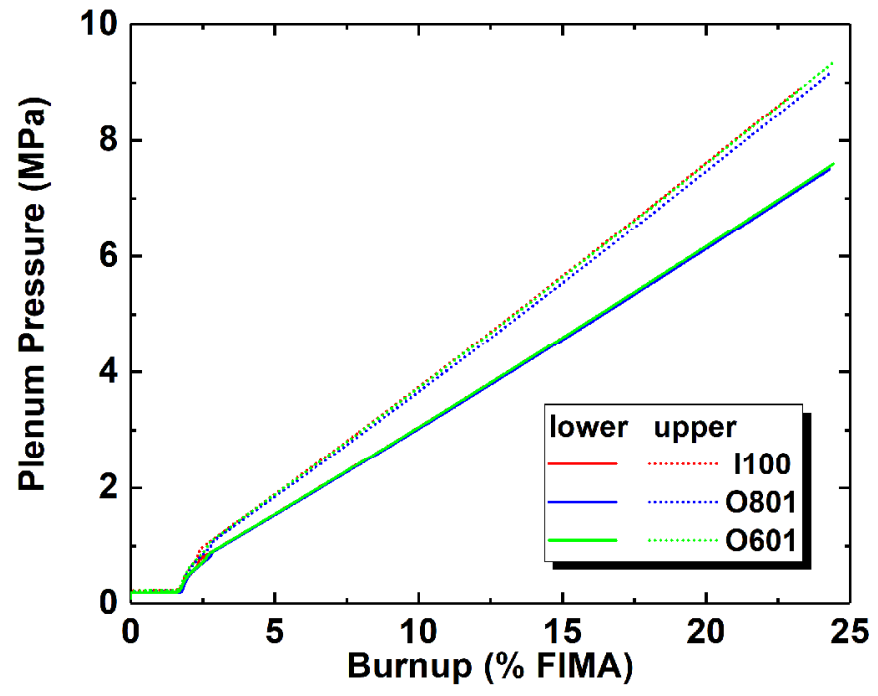

Figure 12. Internal gas pressure depending on locations of gas plenum in AF-SFR. 


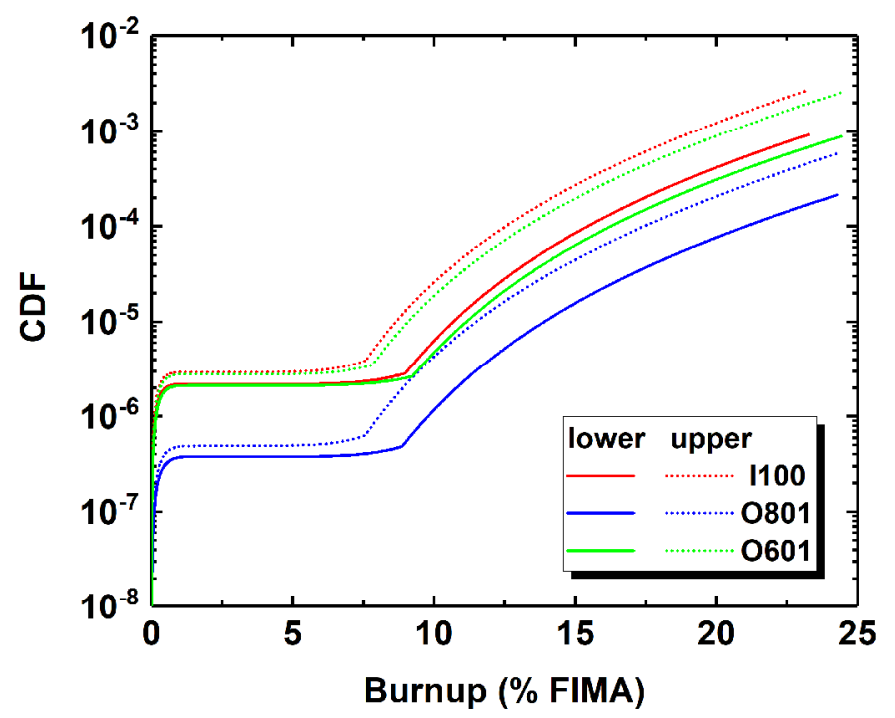

Figure 13. CDF behavior depending on locations of gas plenum in AF-SFR.

- [INL] Evaluation of alternate AFC capsule designs continued in earnest and the report milestone is projected to complete on time. The output of this report will be the commencement of conceptual design of the new experiment hardware. This design concept is hoped to be applied to both the AFCOA and the ATF-1 experiments. (D. Dempsey)

- $\quad$ IINL] Fission gas release results for AFC-3C/3D were further refined with the receipt of gas mass spectrometry results from PNNL. The fission gas release results were generally in-line with expectations with fission gas releases of $70 \% \pm 20 \%$ calculated for most pins. The fission gas release was low for 2 pins, AFC-3C R5 (U-1/2Pd-13Zr) and AFC-3D R3 (U-10Mo), however the burnup of these fuel pins is low enough that porosity may have not yet fully interconnected. One fuel pin, AFC3C R3, had fairly high fission gas release of $91 \%$. This fuel pin was $65 \%$ smear density U-10Zr, and low smear density fuel pins have been reported to have higher fission gas release. (J. Harp)

\begin{tabular}{|c|c|c|c|c|c|}
\hline Rodlet & Composition & $\begin{array}{l}\text { Smear } \\
\text { Density }\end{array}$ & Bonding & Burnup & $\begin{array}{c}\text { Fission } \\
\text { Gas } \\
\text { Release }\end{array}$ \\
\hline AFC-3C R1 & U-10Mo & $75 \%$ & Sodium & $2.3 \%$ & $56 \%$ \\
\hline AFC-3C R2 & U-10Mo & $55 \%$ & $\mathrm{He}$ & $3.2 \%$ & $59 \%$ \\
\hline AFC-3C R3 & $\mathrm{U}-10 \mathrm{Zr}$ & $65 \%$ & Sodium & $2.8 \%$ & $91 \%$ \\
\hline AFC-3C R4 & $\mathrm{U}-10 \mathrm{Zr}$ & $55 \%$ & $\mathrm{He}$ & $3.4 \%$ & $87 \%$ \\
\hline AFC-3C R5 & $\mathrm{U}-1 \mathrm{Pd} / 2 \mathrm{Pd}-13 \mathrm{Zr}$ & $75 \%$ & Sodium & $2.8 \%$ & $38 \%$ \\
\hline AFC-3D R1 & U-10Zr & $55 \%$ & $\mathrm{He}$ & $4.6 \%$ & $85 \%$ \\
\hline AFC-3D R2 & U-4Pd-13Zr & $55 \%$ & Sodium & $2.8 \%$ & $59 \%$ \\
\hline AFC-3D R3 & U-10Mo & $55 \%$ & Sodium & $2.2 \%$ & $42 \%$ \\
\hline AFC-3D R4 & U-10Mo & $55 \%$ & $\mathrm{He}$ & $4.6 \%$ & $64 \%$ \\
\hline AFC-3D R5 & $\mathrm{U}-4 \mathrm{Pd}-13 \mathrm{Zr}$ & $55 \%$ & $\mathrm{He}$ & $2.9 \%$ & $66 \%$ \\
\hline
\end{tabular}

\section{AR Fuel Safety Testing}

- $\quad$ INL] A presentation titled, "New Generation of Transient Testing for SFR Fuels at TREAT," was presented at the ANS meeting in June. (D. Wachs) 


\section{CAPABILITY DEVELOPMENT}

\section{Fuels}

- $\quad$ INL] The TCM sample heater has been assembled without the heating element. The heating element and controller have been ordered as a system. Delivery of the remote sputter coater was delayed due to production backlog. We expect shipment in the next week. The TCM measurement scanning was tested using long cables and feedthroughs. No issues were noted due to the long cables. We are continuing to work with the TPC installation team to procure and test the glove box feedthroughs. (D. Hurley)

For more information on Fuels contact Steven Hayes (208) 526-7255. 


\section{Material Recovery and Waste Forms Development}

\section{PROCESS ChEMISTRY AND INTEgRATION}

- [INL] INL is studying the impacts of gamma radiolysis on the ALSEP minor actinide extraction process. This process uses an organic solvent consisting of a neutral diglycolamide extractant, N,N,N',N'-tetra-2-ethylhexyldiglycolamide (T2EHDGA), and an acidic extractant 2ethylhexylphosphonic acid mono-2-ethylhexyl ester (HEH[EHP]) dissolved in an aliphatic diluent. Several test loop radiolysis experiments were performed in the INL test loop during FY-2017 to examine the impacts of gamma radiolytic degradation processes upon the extraction and scrub sections of the ALSEP flowsheet. In these experiments, the extraction section of the ALSEP flowsheet was irradiated in the INL test loop and the impacts of gamma radiolytic degradation was evaluated by a combination of radiochemical and analytical measurements. The ALSEP investigations at the INL during FY-2018 have focused upon the evaluation of the impacts of gamma radiolytic degradation on the entire ALSEP flowsheet. To this end, the reconditioning loop portion of the INL test loop has been re-configured for ALSEP testing.

The ALSEP flowsheet (as designed by ANL) is the basis for the ALSEP flowsheet to be implemented for the radiolysis and reconditioning test loop experiments. The flowsheet for the solvent reconditioning test will use a solvent composition of $0.75 \mathrm{M} \mathrm{HEH}[\mathrm{EHP}]+0.050 \mathrm{M}$ T2EHDGA. This solvent composition was chosen to remain consistent with earlier INL ALSEP irradiation experiments and the higher HEH[EHP] concentration should result in more conservative metal distribution ratio values in the stripping and solvent wash sections of the flowsheet. The introduction of fresh solvent to the actinide strip section was eliminated since it is not expected to have an impact on the results and goals of the current testing and its implementation in the limited number of contactors available would be complicated. For the remaining sections (scrub, actinide strip, lanthanide strip, solvent wash) of the flowsheet, the aqueous and organic flowrates were adjusted in order to achieve the targeted performance using the minimum number of contactors. The actinide strip will use a citrate buffered HEDTA solution and the lanthanide strip will use $0.3 \mathrm{M}$ TEDGA dissolved in $1.0 \mathrm{M}$ nitric acid. The solvent washing section of the flowsheet is based upon experiments performed earlier this fiscal year at the INL and will consist of a dilute nitric acid wash, two stages of dilute caustic wash and a single acid contact to remove residual caustic from the solvent. (D. Peterman)

- [ORNL] A literature review and preparations for the synthesis of cation exchange membranes with larger ions to improve the selectivity and separation factor of $\mathrm{HTO} / \mathrm{H} 2 \mathrm{O}$ was initiated this month. Although recently reported tritiated water experiments with K-LTA clearly show the retentate HTO concentration is higher than the feed or permeate indicating that HTO is preferentially retained on the feed side of the membrane, the separation factor is lower than expected. These results are relatively consistent for the LTA membranes prepared on two different representative alumina supports (Inopor GmbH, Ceramco). (B. Jubin)

- [ORNL] The Level 3 Milestone M3NT18OR030102051, "Complete tests to produce cermet and grout waste forms using surrogate oxide and nitrate powders," has been completed and the associated report NTRD-MRWFD-2018-000143, ORNL/SPR-2018/877 is undergoing the final steps of approval for release. This report states:

The cermet waste forms were easily prepared in a reproducible fashion. The specimens showed a very uniform microstructure with a continuous copper phase encapsulating the UNF-waste particles. The grout samples were also easily prepared, and the leaching results (ANSI/ANS 16.1) are underway to ascertain the leachability behavior of the grout-encapsulated samples. The achievable waste loadings for the cermet waste forms are higher than for grout. The grouted waste form is more susceptible to the generation of gaseous products because of the radiolysis of the water entrained in the grout. However, there are precedents that indicate grouted samples are acceptable for disposal. Pending the 
results of the leaching tests for the grouted samples, it seems that both waste forms will be acceptable. A disposal path for the samples to be generated during kilogram-scale tests of the advanced pretreatment process has been identified, and disposal appears achievable based on recent shipping experience. (B. Jubin)

\section{Sigma Team for AdVANCEd Actinide ReCyCle}

- [PNNL] The paper below was presented by Vanessa Holfeltz at the 2018 Northwest Regional Meeting of the American Chemical Society, held in Richland, Washington:

- V. Holfeltz, Y. Chen, R.P. Young, G.J. Lumetta, and T.G. Levitskaia, Association of T2EHDGA and HEH[EHP] in the ALSEP solvent. (G. Lumetta)

\section{WASTE FORM DEVELOPMENT AND PERFORMANCE}

\section{Electrochemical Waste Forms}

- [ANL] The report summarizing results and analyses of tests conducted with developmental iron phosphate glass waste forms made at PNNL was drafted. Input from PNNL was incorporated and final SEM analyses are in progress. Activity leads from ANL, PNNL, and INL will discuss the status of activities at each lab and future efforts in early July. (W. Ebert)

\section{Zirconium Recycle}

- [ORNL] The Level 2 milestone M2NT-18OR030105101, "Complete purification test with product from irradiated hulls chlorination," was completed on schedule. Preparations of the purification equipment and glove box were completed and the equipment was installed in the glove box. After approval of the Research Safety Summary (RSS), the initial purification test was made on $63 \mathrm{~g}$ of impure $\mathrm{ZrCl} 4$ previously produced by chlorination of high burnup North Anna PWR UNF nighniobium-alloy zirconium cladding. The test procedure, mass balance, and external radiation measurements are summarized in the Table 1. (B. Jubin)

Table 1. Zr purification procedure, mass balance and dose rates.

\begin{tabular}{|c|c|c|c|c|c|c|}
\hline Step & Task Description & $\begin{array}{c}\text { Material } \\
\text { Recovered } \\
\text { (g) }\end{array}$ & $\begin{array}{c}\text { Jar } \\
\text { Contact } \\
\text { Dose Rate } \\
(\mathbf{m r e m} / \mathbf{h})\end{array}$ & $\begin{array}{c}\text { Sample } \\
\text { I.D. }\end{array}$ & $\begin{array}{l}\text { Sample } \\
\text { aliquot }\end{array}$ & $\begin{array}{c}\text { Sample } \\
\text { Contact } \\
\text { Dose } \\
\text { Rate }^{\text {b }} \\
(\mathrm{mrem} / \mathrm{h})\end{array}$ \\
\hline & $\begin{array}{l}\text { Feed material from jar } \mathrm{Zr}_{2}-4 \\
\text { (impure } \mathrm{ZrCl}_{4} \text { from chlorination } \\
\text { of high-burnup North Anna PWR } \\
\text { UNF high-niobium-alloy cladding }\end{array}$ & 63 & 60 & & & \\
\hline 1 & $\begin{array}{l}\text { Heated to } 170^{\circ} \mathrm{C} \text {, purged with } \\
\mathrm{Ar} / \mathrm{SOCl}_{2} \text { for } 90 \text { minutes. Heated } \\
\text { to } 220^{\circ} \mathrm{C} \text { under argon. Held at } \\
220^{\circ} \mathrm{C} \text { for } 3 \text { hours with } \\
\text { intermittent purge of } \mathrm{Ar} / \mathrm{SOCl}_{2} 6 \\
\text { minutes; Ar } 24 \text { minutes. Cooled } \\
\text { and recovered the desublimed } \\
\text { material. }\end{array}$ & 7 & 60 & $\begin{array}{l}\text { ZRCL- } \\
1\end{array}$ & 0.5 & 6.0 \\
\hline
\end{tabular}


Table 1. (contd.)

\begin{tabular}{|c|c|c|c|c|c|c|}
\hline Step & Task Description & $\begin{array}{c}\text { Material } \\
\text { Recovered } \\
\text { (g) }\end{array}$ & $\begin{array}{c}\text { Jar } \\
\text { Contact } \\
\text { Dose Rate } \\
(\mathbf{m r e m} / \mathbf{h})\end{array}$ & $\begin{array}{l}\text { Sample } \\
\text { I.D. }\end{array}$ & $\begin{array}{l}\text { Sample } \\
\text { aliquot }\end{array}$ & $\begin{array}{c}\text { Sample } \\
\text { Contact } \\
\text { Dose } \\
\text { Rate }^{b} \\
(\mathrm{mrem} / \mathrm{h})\end{array}$ \\
\hline 2 & $\begin{array}{l}\text { Heated remaining material to } \\
350^{\circ} \mathrm{C} \text { and held for } 3 \text { hours. } \\
\text { Argon flow } 80 \mathrm{sccm} \text { for } \sim 20 \\
\text { minutes; } 100 \mathrm{sccm} \text { for } \sim 100 \\
\text { minutes; } 150 \mathrm{sccm} \text { for } \sim 60 \\
\text { minutes: Cooled and recovered } \\
\text { the desublimed material. }\end{array}$ & 34 & $20-38$ & $\begin{array}{l}\text { ZRCL- } \\
2\end{array}$ & 0.5 & 1.2 \\
\hline 3 & $\begin{array}{l}\text { Heated remaining material to } \\
350^{\circ} \mathrm{C} \text { and intermittently purged } \\
\text { with Argon }(10 \text { minutes }) \text { and } \\
\text { Argon } / \mathrm{SOCl}_{2}(10 \text { minutes }) \text { for } 3 \\
\text { hours.70 minutes @ } 150 \mathrm{sccm} \\
\text { and } 110 \text { minutes@ } 300 \mathrm{sccm} \text {. } \\
\text { Cooled and recovered the } \\
\text { sublimed material. }\end{array}$ & $19^{\mathrm{C}}$ & 44 & $\begin{array}{l}\text { ZRCL- } \\
3\end{array}$ & 0.5 & 2.4 \\
\hline & Total mass balance & $60(95 \%)$ & & & & \\
\hline & \multicolumn{6}{|c|}{${ }^{\mathrm{a}}$ The jar was retracted into the glovebox glove for this measurement. } \\
\hline & \multicolumn{6}{|c|}{$\begin{array}{l}{ }^{\mathrm{b}} \text { This dose rate was on the sample vial following removal from the glovebox and wiped down } \\
\text { in hood. }\end{array}$} \\
\hline & \multicolumn{6}{|c|}{$\begin{array}{l}{ }^{\mathrm{c}} \text { The amount recovered from the collection pot was } 8 \mathrm{~g} \text {, and the amount recovered from the } \\
\text { spherical ball joint area was } 11 \mathrm{~g} \text {. }\end{array}$} \\
\hline \multicolumn{7}{|c|}{ Total of recovered material is $60 \mathrm{~g}$} \\
\hline
\end{tabular}

\section{Advanced Waste Form Characterization}

- $\quad$ [ANL] The status report on parameterizing the ANL Stage 3 model (NTRD-MRWFD-2017-000197) was revised to include recent results and analyses and sections describing extraction of parameter values are being added. (W. Ebert)

- [ANL] Initial drafts of reports summarizing the approaches developed for finalizing the glass degradation model and for establishing a test method for radioiodide-bearing waste forms were prepared to support discussion with collaborators at PNNL. These will describe cooperative and collaborative activities at the two labs. (W. Ebert)

- $\quad[$ PNNL] A letter report on iodine waste form durability testing was written and submitted to campaign leadership in completion of milestone M4NT-18PN030105093A. The report details the results from modified single-pass flow-through (SPFT) testing of samples provided by other campaign efforts to capture and immobilize iodine. Specifically, three samples of hot isostatically pressed (HIPed) silver mordenite (AgZ) were obtained from Oak Ridge National Laboratory (Work Package NT-18OR03010702) and 2 samples of spark plasma sintered (SPS) silver-functionalized aerogels (SFA) were obtained from Pacific Northwest National Laboratory (Work Package NT18OR03010703). The tests examined the resistance to accelerated aqueous corrosion at $90{ }^{\circ} \mathrm{C}$ in $\mathrm{pH}$ (at room temperature) $4-11$ solutions. The SPS-SFA samples, with much higher I loading than the HIP-AgZ ( $\sim 30 \%$ relative to $\sim 7 \%)$, unsurprisingly exhibited higher I and Si release rates than the AgZ 
samples at $\mathrm{pH}$ (RT) 7 and 11 but equivalent rates at $\mathrm{pH}$ (RT) 9. The SPS-SFA sample with higher Si content continuously exhibited lower Si and I dissolution rates compared with its lower Si SFA counterpart. Insight into the progression of individual microstructural features during corrosion was observed for both the AgZ and SPS-SFA samples. At pH (RT) 7 and below, the AgZ samples appeared to undergo congruent dissolution. At pH (RT) 9 and above, corrosion appeared to be most severe at K-containing locations on the sample, with the continuous Si matrix (containing the Ag and I) being more resistant. The SPS-SFA samples showed corrosion primarily in the continuous matrix region while larger Si particles were observed to be more corrosion resistant. Corrosion of Si particles appeared to move inward from the boundaries. (J. Ryan)
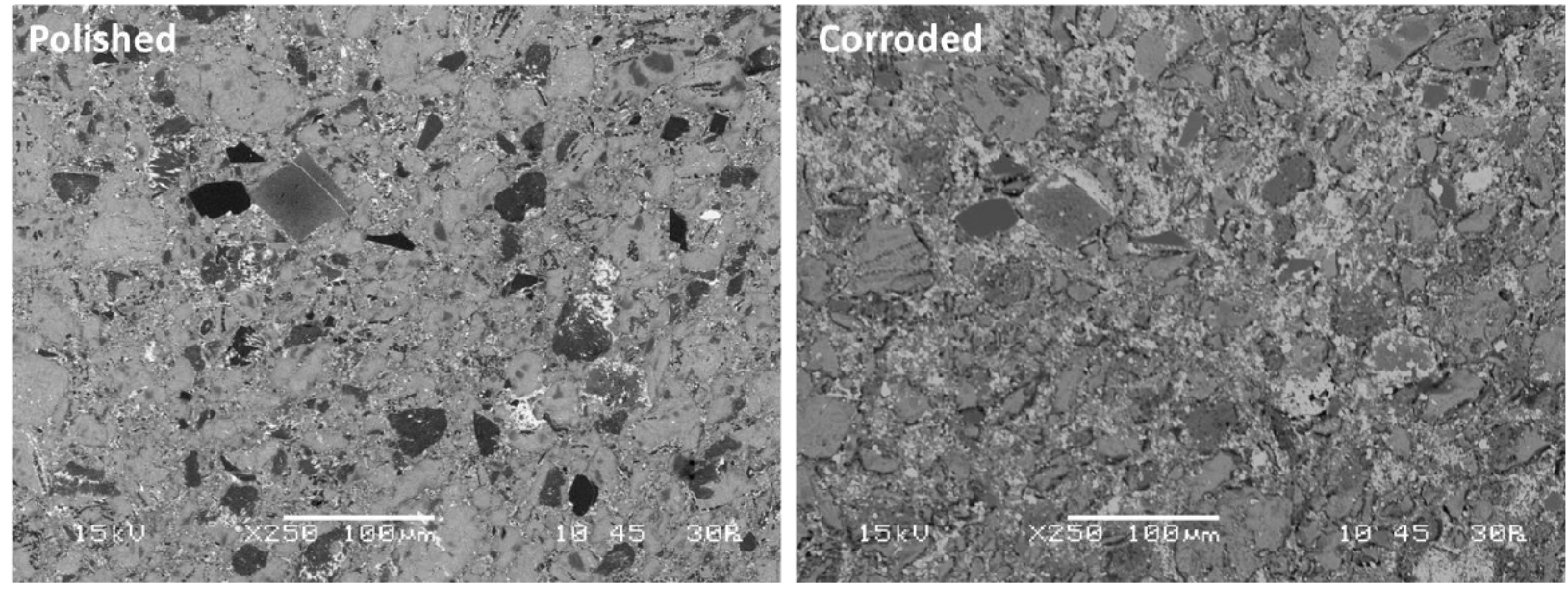

Figure 14. Scanning electron microscopy showing the AgZ 1-7 sample before and after SPFT at $\mathrm{pH}_{(\mathrm{RT})} 11$.

- [PNNL] Reviews of the manuscript titled, "Adaptation of the GRAAL Model of Glass Reactivity to Accommodate Non-linear Diffusivity," submitted earlier this year to the Journal of Nuclear Materials have been received. A revised manuscript is being prepared.

- $\quad$ [PNNL] Dr. Kerisit gave an invited presentation at the American Chemical Society Northwest Regional Meeting (NORM2018) in Richland, WA on June 25th, 2018 on modeling nuclear waste glass corrosion. Ms. Jan, a PhD student visiting PNNL from CEA, also gave a presentation at the NORM2018 conference on the modeling work she has been performing during her visit." (S. Kerisit)

\section{DOMESTIC ELECTROChemical PROCESsing}

- [ANL] Initial plans for salt and metal waste form activities are being developed and will be discussed with INL staff in early July. (W. Ebert)

\section{Sigma TEAM FOR OfF-GAS}

- [INL] Planning and preparations continue in several areas for a new phase of deep-bed iodine adsorption testing for organic iodide species in simulated vessel off-gas. Work activities include (a) modifications for higher gas flowrates by using purified and filtered building compressed air instead of compressed air cylinders, (b) evaluations of gas chromatographic analysis of iodododecane, a candidate organic iodide, and (c) modifications to the sorbent bed columns to enable periodic sorbent sampling and analysis. Testing will begin when these modifications and preparations are complete. (Soelberg, Welty)

- [ORNL] The operational envelope of the scrubber (target liquid and gas flow rates, as well as the L/G ratio) has been identified through a series of testing with $\mathrm{CO} 2$ only. $\mathrm{CO} 2$-only testing resulted in $\mathrm{CO} 2$ 
DFs ranging from 10-40. The LiCor instrument, used for CO2 measurements, was corroded during testing and the failed parts will be replaced. Testing is proceeding with iodine-bearing test mixtures. (B. Jubin)

- [ORNL] The final report for the milestone to evaluate the results of extended duration test of VOG sorbents to support the determination of key engineering parameters has been prepared and is undergoing internal review. (B. Jubin)

- [ORNL] Work continues on the task to complete the initial series of Ru adsorption optimization studies and provide recommended changes to the assumptions used in the analysis of an integrated off-gas systems. Three experimental tests have been completed characterizing the adsorption of volatile $\mathrm{Ru}$ from a dry gas stream by metal mesh, and analysis of the sorbents from these tests will provide the required data for milestone completion. Two of these tests set the sorbent operating temperature of $150^{\circ} \mathrm{C}$, with the first test delivering $5 \times$ the amount of $\mathrm{Ru}$ as was delivered in the second. This allows an assessment of the sorption or deposition behavior of $\mathrm{Ru}$ on the metal mesh as a function of increased total Ru delivery. The third test set the sorbent operating temperature at $250^{\circ} \mathrm{C}$ and delivered a total amount of Ru near that of second run. The sorbents from these tests have been removed and the loading ( wt $\%$ ) has been determined. Selected sorbents will be analyzed by optical microscopy, SEM and total dissolution/ICP-MS to fully characterize the deposition behavior of Ru in this system. (B. Jubin)

- [ORNL] The second journal article describing the analysis of the contents of selected Kr-85 legacy capsules has been approved by ORNL management and was submitted to Nuclear Technology on June 6 and is in the journal review process. This completes milestone M3NT-18OR030107028. A summary of the article is provided below. (B. Jubin)

During a removal of legacy materials from one hot cell at the Idaho National Laboratory (INL) in 2010, five metal capsules and some loose zeolite material were identified as krypton ( $\mathrm{Kr})$ immobilization test specimens produced in the late 1970's under the Airborne Waste Management Program. This specific R\&D effort examined the encapsulation of $85 \mathrm{Kr}$ within a collapsed zeolite structure for use as a potential waste form for long-term storage. The recovered capsules appeared to have been placed to the side and remained untouched after the Airborne Waste Management Program was halted in the mid-1980s. These reclaimed capsules and loose material presented a unique opportunity to study a potential $85 \mathrm{Kr}$ waste form after three half-lives have elapsed. The first phase of this study included two parts; the first was to assess the physical condition of the capsule walls, and the second was to examine the $\mathrm{Kr}$-containing material within the capsules. The first part of the study was previously reported and noted that substantial corrosion was observed throughout each capsule wall of the two previously breached capsules that were examined. One of these capsules had been hot isostatic pressed (HIPed) and one was not HIPed. The second part of the study examined the materials contained in the two previously breached capsules. There appears to be a relatively uniform distribution of $\mathrm{Kr}$ and rubidium $(\mathrm{Rb})$ throughout the pellets examined. The chemical composition of the pellets appears to be consistent with 5A molecular sieves. The material contained within HIPed capsules showed $\sim 1$ at. \% lead $(\mathrm{Pb})$. The origin of the $\mathrm{Pb}$ is currently indeterminate. X-ray diffraction analysis shows a significant shift from the 5A structure, most likely due to the $\mathrm{Kr}$ encapsulation / sintering process that occurred when the samples were made. Calculations based on the energy dispersive spectrometry (EDS) elemental analysis show a residual $\mathrm{Kr}$ level within the pellets that is within a factor of 2 of the reported $\mathrm{Kr}$ capacities for this type of processed material. This provides a clear indication that a significant fraction of the $\mathrm{Kr}$ initially encapsulated in the material remained within the waste form even following a significant breach of the capsule wall. As a result, it would appear that this $\mathrm{Kr}$ immobilization method, even in non-HIPed form, is very promising as a waste form for long-term storage. The successful analysis of these two breached capsules forms a solid basis for the future analysis of the remaining unbreached capsules, which 
offers the opportunity to provide an even more complete understanding of the long-term $\mathrm{Kr}$ retention performance of this promising waste form.

- [ORNL] Progress continued on the task to determine the impact of variations in NO, NO2 and water concentrations on iodine adsorption rates. A test was conducted to characterize the adsorption of $\mathrm{CH} 3 \mathrm{I}$ at $135^{\circ} \mathrm{C}$ from a dry air stream by AgZ. The observed loading was lower than expected, at $2.8 \%$. The sorbent is being re-tested with elemental iodine to verify total iodine capacity.

Additionally, the feed stream was tested using GC-MS to verify CH3I delivery to the TGA. This issue coupled with the HFIR operating schedule (HFIR is required for the neutron activation analysis of the iodine loaded sorbent) will result in a delay of several months in the completion of this milestone. (B. Jubin)

- $\quad$ OORNL] A static iodine loading system has been designed that will allow uniform loading of I2 onto $\mathrm{AgZ}$ sorbent in the quantities required for large-format samples. Two sets of replicate samples will be produced with target iodine saturation levels of 50 and 100\%. (B. Jubin)

- $\quad$ PNNL] PNNL personnel spoke to Parker and Hannifin regarding the engineered form particles using their trade secret. Parker and Hannifin have agreed to convert MOF particles into MOF cores. Experiments are in progress to scale up and ship to Parker and Hannifin. (P. Thallapally)

\section{FLOWSHEET DEMONSTRATIONS}

- [PNNL] Two papers were presented at the 2018 Northwest Regional Meeting of the American Chemical Society, held in Richland, Washington. The two papers presented were:

- $\quad$ G.J. Lumetta, J.R. Allred, S.A. Bryan, G.B. Hall, T.G. Levitskaia, A.M. Lines, S.I. Sinkov, Support functions for testing of a uranium-plutonium co-decontamination flowsheet, presented by Jarrod Allred.

- $\quad$ G.B. Hall, J. Allred, A.M. Lines, S.I. Sinkov, S.A. Bryan, and G.J. Lumetta, Controlled Pu:U Ratios in a modified PUREX (CoDCon) solvent extraction flowsheet, presented by Gabe Hall. (G. Lumetta)

- $\quad$ [SNL] The 2nd CoDCon test at PNNL was attended to adjust the safeguards and process control model. The test was used modify the modeled separation factors in order to mimic actual results. This will be used to inform future modeling efforts. (B. Cipiti)

For more information on Material Recovery and Waste Forms Development contact Terry Todd (208) 526-3365 


\section{MPACT Campaign}

\section{MANAGEMENT AND INTEGRATION}

\section{NTD \& Technical Support}

- [LANL] Met with LANL MPACT personnel to review status of current MPACT-funded technologies. Continued development of short and long term MPACT strategic plan, including outreach and coordination efforts. Prepared for MPACT Advanced Integration Meeting to meet 2020 milestones. Meeting to be held at LANL in July 2018. Met with LANL Advanced Fuels campaign $\mathrm{R} \& \mathrm{D}$ personnel to understand potential areas of cooperation.

\section{SAFEgUARDS AND SECURITY BY DESIGN - ECHEM}

\section{Voltammetry}

- $\quad$ [ANL] Long-duration tests of sensor performance continued. A second month of continuous testing of the electrochemical sensor was completed, further confirming the stability and repeatability of measurements.

- [INL] A Macor shroud, to isolate the probe from the Integrated Recycling Test (IRT) oxide reduction furnace, is being fabricated. The shroud is needed to complete the assembly of the probe that will be installed in the Hot Fuel Examination Facility (HFEF) hot cell.

\section{Sensor for Measuring Density and Depth of Molten Salt}

- [INL] The triple bubbler system has been operating in the Integrated Recycling Test (IRT) electrorefiner located in the Hot Fuel Examination Facility (HFEF) hot cell. The system still needs to be calibrated. In order to better set the physical parameters of the bubbler, as well as to validate the bubbler calibration, an accurate method to measure the depth is needed. A digital height gauge is being modified to make these measurements. Many of these modifications are currently in fabrication or have been purchased.

\section{Electrochemical Signatures Development}

- [LANL] The Advanced Burner Test Reactor metal fuel-assembly (FA) model was selected as a starting point for numerical simulations executed using the experimental version MCNP6 for chain analysis.. Analytical modeling will begin with $235 \mathrm{U}$ and 239Pu neutron-induced fission, first individually, and then jointly using an isotopic probability factor. Radiation efforts regarding the MCNP6 moving objects analysis of moving radiation sources, including HDND analysis, and the theoretical fission chain model development concluded at the end of June. Two reports have been produced: "Calculation of Time-Dependent Radiation Signatures for Electrochemical Reprocessing Using MCNP6 Moving Objects FY18 Summary Report in Support of MPACT" and "Preliminary Efforts on Fission Chain Radiation Signatures for Pyroprocessing FY18 Summary Report in Support of MPACT" (M3NT-18LA040104041).

\section{Microfluidic Sampler}

- $\quad$ [ANL] A flow cell pneumatic droplet generator was fabricated in acrylic by rapid prototyping. The flow cell was assembled and instrumentation is being installed to run the system. When installation is complete, the system will be tested using water. Planning discussions have taken place with the Quad City Manufacturing Laboratory regarding a stainless steel 3-D print of the flow cell droplet generator 
prototype, and with TCS Micropumps regarding the fabrication of a molten salt compatible micropump.

\section{Electrochemical Sensor}

- [INL] Two Na-beta" alumina tubes were successfully ion exchanged in pure UCl3 salt, at 770®C for $\sim 150 \mathrm{hrs}$. The reaction between the Na-beta" alumina and UCl3 appears very minimum, better than the previous ion exchange experiment in $\mathrm{UCl} 3$ at $795{ }^{\circledR C}$. One U-sensor was tested in $\mathrm{LiCl}-\mathrm{KCl}-$ $\mathrm{UCl} 3$ salt. The results can be considered reasonably repeatable. The other U-sensor will be tested for double-checking. From the OCP measurements before $\mathrm{UCl} 3$ additions, the U-sensor is close to equilibrium after about $100 \mathrm{hrs}$.

\section{ADVANCED INTEGRATION}

\section{Advanced Integration (Facility Models)}

- $\quad$ [SNL] The milestone report, "Electrochemical Safeguards Modeling to Support the Virtual Facility Distributed Test Bed," was completed (M3NT-18SN040105031)

\section{EXPLORATORY RESEARCH / FIELD TESTS}

\section{Microcalorimetry}

- [LANL] Made significant progress on the microcalorimeter instrument. The rebuilt SLEDGEHAMMER array and upgraded amplifiers are working well. Energy resolution is consistently around $70 \mathrm{eV} \mathrm{FWHM}$ at $100 \mathrm{keV}$, or $\sim 8$ times better than a high-purity germanium detector. Both microwave circuits and sides of the array show similarly good performance. Pixel yield is approximately $70 \%$, up from less than $50 \%$ before the rebuild. We have also reconfigured the intermediate frequency readout electronics for improved stability and reduced size.

\section{High Dose Neutron Detector}

- $\quad$ [LANL] Two repaired HDND pods were tested at LANL and shipped to INL for further measurements. Discussions on miniature HDND junction box design were initiated with PDT. The main development this FY will focus on 'in-cell friendly' junction box development to ease handling, use and potential replacement activities while inside hot cell environment.

For more information on MPACT contact Mike Browne at (505) 665-5056. 


\section{Fuel Cycle Options Campaign}

\section{CAMpaign MANAGement}

- $\quad[\mathbf{A N L}]$ A document on the cost/benefits analysis of fast reactor recycle versus once-through fuel cycles was completed, upon request by DOE NE management. A quality product was delivered in a very short turn-around time, and follow-on requests for additional modifications and quantitative supporting material were provided.

- $\quad$ AANL, INL] Initiated the formal engagement with ANL and INL of key VTR personnel for the riskbased cost estimation work to be performed by the SA\&I campaign. A conference call was held with this purpose, and a scope of work was better defined during the call.

\section{EQUILIBRIUM SYSTEM PERFORMANCE (ESP)}

\section{Performance of Fuel Cycle Systems}

- $\quad$ [BNL/PSU] Fuel cycle fact sheets for all concepts assigned to BNL have been forwarded to ANL:

- VVER-Based Floating Reactor Concepts (VBER -150/VBER-300)

- Advanced Customer-friendly Practicable Reliable (ACPR50S) Small Modular Reactor

- Marine Based Organically Cooled Nuclear Reactor for Enhanced Economics and Safety

- Flexblue ${ }^{\circledR}$ Marine Based Transportable Small Modular Reactor

- VVER-Based Floating Reactor Concepts with enrichment greater than 5/w/o (KLT-40S, ABV6M, RITM-200)

- Fuel cycle(s) of Russia

- eVinci reactor

- [ANL, BNL, INL, ORNL] Collected the information on the advanced nuclear energy systems being developed by industry, universities, and national labs for informing DOE-NE on potential performance in the context of the entire nuclear energy system. The collected information includes advanced separation processes, micro-size reactors, marine reactors, and national fuel cycle concepts of foreign countries. The detailed fuel cycle information on the nuclear energy systems was summarized using the template that was developed in the campaign.

- [ANL] Discussed with DOE management and revised per that input the preliminary summary of the U.S. perspective and the Wyoming Case Study on the socio-economic benefits of uranium mining. This information will be discussed at the upcoming meeting of "NEA Expert Group on Uranium Mining Economic Development (UMED)", along with the overall scope of the report. The preliminary summary and discussion with DoE management was in preparation for the meeting.

- [INL] Finalized ESP reviewing activities for three nuclear reactors/systems. Those are (1) India's three-stage fuel cycle concept, (2) URENCO's U-Battery ${ }^{\circledR}$ and (3) Westinghouse's eVinciTM micro reactor (assuming it is a fast reactor). Summaries were submitted to ANL along with their references.

- $\quad$ [ORNL] Work has continued with Penn State University on improving the transmutation database. Scripts have been finalized that automatically generate recipes for both ORION and Cyclus by directly querying the transmutation database. Furthermore, an interactive data visualization tool has been produced that can directly link up with the data from the transmutation database. 


\section{Economic Analysis Capabilities and Assessments}

- [ANL] The report entitled "Report on the Update of Fuel Cycle Cost Algorithms" by F. Ganda, et al. was submitted to the campaign management. This is a deliverable in fulfillment of the Level 2 milestone, M2NT-18AN120102012 under the work package "NT-18AN12010201 - Equilibrium System Performance (ESP) - ANL." Mr. J. Buelt of JLB EnvEn Solutions reviewed the report, and the findings of the work on the cost of the 1000 MWth Advanced Burner Reactor were discussed with the fast reactor campaign NTD.

- [ANL, ORNL] F. Ganda participated in the "Panel Session on Advanced Closed Fuel Cycles - The Economic Challenge" on June 19, 2018, during the ANS Annual Meeting in Philadelphia. The session, which also included as invited speakers, Andrew Worrall (ORNL), Paul Murray (ORANO), Andrew Sowder (EPRI), Tim Tinsley (UK-NNL), was chaired by Steve Napier (UK-NNL) and well attended with multiple interesting questions.

- $\quad[\mathrm{ANL}]$ The comments on the NE-COST website provided by the SA\&I Campaign lab leads were implemented. The process for public release of the website was initiated: a pdf copy of the website was prepared and submitted through the process for external release of ANL documents.

Additionally, a scan for the website's vulnerabilities was successfully completed, in order to be able to formally allow un-restricted public access.

- [ANL] Continued the preparation of the Cost Basis Milestone, due September 30, 2017. The conference calls were increased to a weekly frequency, and the efforts were focused on the integration of the newly uncovered cost data for various facilities into a consistent F2/D2 module on pyroprocessing and remote fabrication. Dr. Mark Williamson (ANL) was engaged in order to better understand the cost drivers for certain data point which appeared inconsistent with the rest of the available information. Additionally, new cost data were uncovered for the DUPIC process, from the Korean experience. However, since DUPIC is not the same functional process as pyro, it was decided that the F2/D2 module should be split in two parts, with the new one being for DUPIC and similar process (e.g. CARBOX, for which we also have newly-uncovered cost data), involving a less thorough separation of fission products, but still requiring remote handling for the refabrication part. This will increase the range of applicability of the F2/D2 module. Separately, the work on the revision of the F1-1 module with material from the NASAP program is continuing.

- [INL] Continued working on the Cost Basis Report update. Worked with Kent Williams (ORNL, retired) to review another study from KAERI researchers, this one the PRIDE facility piloted in South Korea for pyroprocessing. Then reviewed the technical studies listed, and underlying the cost basis reported, in F2D2 to find the key assumptions on fuel parameters. Based on this worked with Williams to develop a clarifying figure to include in F2D2. Continued working on Chapter 8 of the CBR to formalize the section on escalation and standard methods.

\section{Equilibrium System Performance (ESP) Tools Development}

- [BNL/PSU, ORNL] Work on the Transmutation Data Library task continued.

\section{DEVELOPMENT, DEVELOPMENT AND IMPLEMENTATION ISSUES (DDII)}

\section{Technology and System Readiness Assessment (TSRA)}

- [INL, BNL, ANL, LLNL] "Report on the Technology and System Readiness Assessment of a Fast Reactor Recycle System” satisfying M2NT-18IN120103032 was submitted on schedule on June 29, 2018. 
- [LLNL] Provided independent review of the INL Level-2 program report: "Technology and System Readiness Assessment of a Fast Reactor Recycle System" (NTRD-FCO-2018-000446), delivered June 29, 2018.

- $\quad$ [ANL] Continued the technology and system readiness assessment of a sodium-cooled fast reactor (SFR) in a U/TRU continuous recycle nuclear energy system. The assessment of technology readiness levels of the critical technology elements and the system readiness level of the SFR subsystems were completed and contributed to the development of the M2 report.

- [INL] Continued work with technical experts who are applying the TSRA process to the separations system within the EG24 cycle. Assisted in the preparation of the "Technology and System Readiness Assessment of a Fast Reactor Recycle System" report which was completed on June 29.

- [INL, BNL, ANL, LLNL] Regularly scheduled telecons continued to finalize the M2 report.

\section{Transition Analysis Studies}

- [ANL] E. Hoffman participated in a panel session on "Challenges Associated with the Back End of the Molten Salt Reactor" during the ANS Annual Meeting in Philadelphia and gave a presentation on "Fuel Cycle Options Study Summary - MSR", which is a summary of the performance of molten-salt reactors in various fuel cycles.

- [ANL, ORNL] The draft M3 milestone on technology specific transitions was written and internally reviewed. The final draft is currently underway to accommodate the internal review comments.

- [ANL] E. Hoffman, et al. developed a presentation, entitled "Impact of Technology Characteristics on Transition to a Fast Reactor Fleet" for the 3rd Technical Workshop on Fuel Cycle Simulation, to be held in Paris, July 2018. This presentation contains a summary of the work completed on the sensitivities of transition results to technology and system characteristics with a focus on the modeling and simulations used to inform this study.

- [ORNL] The results from transition analyses performed using a fast MSR model in ORION were summarized in an internal ORNL report and will form the basis of a journal article. This report is currently undergoing internal peer review. A portion of the ORION results on the single fast MSR were compiled together for a presentation at the "3rd Technical Workshop On Fuel Cycle Simulation" in Paris.

- [ORNL] The summer intern has continued the modeling of the fast spectrum MSR fuel cycle analyses. Models have been developed for four different fast spectrum MSR systems, and has collected the isotopic removal, fueling, and operation information necessary to perform a whole-life reactor physics fuel cycle simulation.

- [INL] Updated the economic transition cost model for analysis of the case of EG30. Complied a slide deck that outlines the preliminary findings of the econ transition to be presented at the 3rd Fuel Cycle Simulation Workshop in Paris.

\section{Regional and Global Analysis}

- [ANL] N. Stauff hosted a special session, entitled "Load Following Attributes for Nuclear" during the 2018 ANS Annual Meeting in Philadelphia. The invited panelists in this session were Andrew Sowder (EPRI), John Siphers (Duke Energy), Jose Reyes (NuScale), and Sonny Kim (PNNL). The session was well attended and triggered a lot of questions from the audience.

- $\quad[\mathrm{PNNL}]$ Attended ANS Annual Meeting in Philadelphia. Gave presentation and participated in session on Load Following Attributes for Nuclear. Additionally, exploring long-term renewable and 
nuclear energy interactions and the impact of transportation electrification on electricity demand using the GCAM model.

- [ANL] Continued working on the EDGAR code (Economic Dispatch Genetic AlgoRithms), to enable its use for energy market analysis within the SA\&I Campaign. A meeting involving the EDGAR developers and campaign management was held on June 8, 2018 to communicate the activity, its progress and challenges.

\section{Development, Deployment, and Implementation Issues (DDII) Tools Development}

- [ANL] B. Feng, et al. developed a presentation, entitled "Modeling MSRs in DYMOND" for the 3rd Technical Workshop on Fuel Cycle Simulation, to be held in Paris, July 2018. This presentation summarizes how MSRs can be modeled using system-dynamics code of DYMOND.

- [INL] Refined and documented EG-23 and EG-30 scenario variations for the analysis of the impact of separations capacity scheduling on economic performance during transition.

For more information on Fuel Cycle Options contact Temitope Taiwo (630) 252-1387. 


\section{Joint Fuel Cycle Study Activities}

- LWR fuel inventory within HFEF was reviewed, inventory gathered and decladding completed as a step to quantify material available for proposed interim LWR experiment runs.

- Oxide reduction system startup activities were initiated in preparation of processing interim LWR fuel. These activities included replacing portions of the off-gas system, salt level and salt concentration adjustments.

- Analytical results were received for prior ER Salt and U/TRU material samples.

For more information on Joint Fuel Cycle Studies Activities contact Ken Marsden (208) 5337864. 


\section{AFCl-HQ Program Support}

\section{UNIVERSITY PROGRAMS}

Site: University Research Alliance at West Texas A\&M University in Canyon TX, and the following universities: University of Michigan, University of Tennessee, University of California at Berkeley, Texas A\&M University, Vanderbilt University, University of Idaho, Oregon State University, Kansas State University, Northwestern University, University of Nevada at Las Vegas, Clemson University, Rensselaer Polytechnic Institute, Purdue University, Georgetown University, Virginia Commonwealth University, Florida International University, and other universities.

\section{Universities engaged in Nuclear Technology research via URA programs since 2001:}

\author{
Boise State University \\ Boston College \\ Clemson University \\ Colorado School of Mines \\ Georgia Institute of Technology \\ Georgetown University \\ Idaho State University \\ Florida International University \\ Florida State University \\ Kansas State University \\ Massachusetts Institute of Technology \\ Missouri University of Science and \\ Technology \\ North Carolina State University \\ Northern Illinois University \\ Northwestern University \\ Ohio State University \\ Oregon State University \\ Pennsylvania State University \\ Purdue University \\ Rensselaer Polytechnic Institute \\ Rutgers University \\ Texas A\&M University
}

\author{
University of Arkansas \\ University of California at Berkeley \\ University of California at Santa Barbara \\ University of Chicago \\ University of Cincinnati \\ University of Florida \\ University of Idaho \\ University of Illinois at Urbana-Champaign \\ University of Michigan \\ University of Missouri \\ University of Nevada at Las Vegas \\ University of New Mexico \\ University of North Texas \\ University of Notre Dame \\ University of Ohio \\ University of South Carolina \\ University of Tennessee at Knoxville \\ University of Texas at Austin \\ University of Virginia \\ University of Wisconsin \\ Vanderbilt University \\ Virginia Commonwealth University \\ Washington State University
}

\section{INNOVATIONS IN NUCLEAR TECHNOLOGY R\&D AWARDS}

\section{Summary Report}

\section{Innovations in Nuclear Technology R\&D Awards}

- University Research Alliance completed processing award checks for the 2018 Innovations Awards winners, and mailed them to the recipients.

- University Research Alliance received letters of congratulations from the DOE for the 2018 Innovations Awards winners, and included them with the award checks.

- University Research Alliance prepared press releases on behalf of the 2018 Innovations Awards winners. Winners' university department heads, advisors, and newspapers are among those who are formally notified of their achievement. 
- University Research Alliance posted the 2018 Innovations Awards announcement on the nucleartechinnovations.org website with the winners' information.

\section{Innovators' Forum}

- University Research Alliance processed travel reimbursements for the Innovations Awards winners who attended the 2018 Innovators' Forum, a meeting designed to train students in techniques that encourage innovative thinking, which took place May 21-23 at the Sheraton Nashville Downtown Hotel.

- University Research Alliance is compiling student evaluations from the 2018 Innovators' Forum and using them to improve future events.

\section{Other Activities}

- University Research Alliance continued to update the Innovations Awards announcement distribution list and remove people who have asked to be removed from the list.

For more information on the University Research Alliance contact Cathy Dixon (806) 651-3401. 